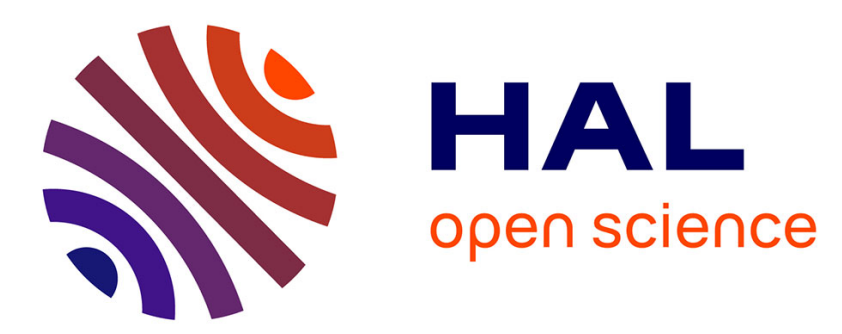

\title{
Differential effects of anti-apoptotic Bcl-2 family members Mcl-1, Bcl-2, and Bcl-xL on Celecoxib-induced apoptosis
}

\author{
Justine Rudner, Simon Johannes Elsaesser, Arndt-Christian Müller, Claus \\ Belka, Verena Jendrossek
}

\section{To cite this version:}

Justine Rudner, Simon Johannes Elsaesser, Arndt-Christian Müller, Claus Belka, Verena Jendrossek. Differential effects of anti-apoptotic Bcl-2 family members Mcl-1, Bcl-2, and Bcl-xL on Celecoxibinduced apoptosis. Biochemical Pharmacology, 2009, 79 (1), pp.10. 10.1016/j.bcp.2009.07.021 . hal00529099

\section{HAL Id: hal-00529099 \\ https://hal.science/hal-00529099}

Submitted on 25 Oct 2010

HAL is a multi-disciplinary open access archive for the deposit and dissemination of scientific research documents, whether they are published or not. The documents may come from teaching and research institutions in France or abroad, or from public or private research centers.
L'archive ouverte pluridisciplinaire HAL, est destinée au dépôt et à la diffusion de documents scientifiques de niveau recherche, publiés ou non, émanant des établissements d'enseignement et de recherche français ou étrangers, des laboratoires publics ou privés. 


\section{Accepted Manuscript}

Title: Differential effects of anti-apoptotic Bcl-2 family members Mcl-1, Bcl-2, and Bcl-xL on Celecoxib-induced apoptosis

Authors: Justine Rudner, Simon Johannes Elsaesser, Arndt-Christian Müller, Claus Belka, Verena Jendrossek

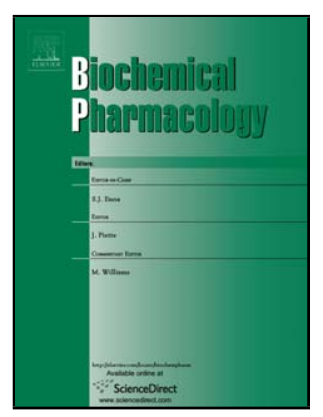

PII: S0006-2952(09)00665-0

DOI: doi:10.1016/j.bcp.2009.07.021

Reference: BCP 10271

To appear in: $\quad B C P$

Received date: $\quad$ 13-4-2009

Revised date: 23-7-2009

Accepted date: $\quad$ 27-7-2009

Please cite this article as: Rudner J, Elsaesser SJ, Müller A-C, Belka C, Jendrossek $\mathrm{V}$, Differential effects of anti-apoptotic Bcl-2 family members Mcl-1, Bcl-2, and Bcl-xL on Celecoxib-induced apoptosis, Biochemical Pharmacology (2008), doi:10.1016/j.bcp.2009.07.021

This is a PDF file of an unedited manuscript that has been accepted for publication. As a service to our customers we are providing this early version of the manuscript. The manuscript will undergo copyediting, typesetting, and review of the resulting proof before it is published in its final form. Please note that during the production process errors may be discovered which could affect the content, and all legal disclaimers that apply to the journal pertain. 


\section{Differential effects of anti-apoptotic Bcl-2 family members Mcl-1, Bcl-2, and Bcl-xL on Celecoxib-induced apoptosis}

Justine Rudner ${ }^{1}$, Simon Johannes Elsaesser ${ }^{1,2}$, Arndt-Christian Müller ${ }^{1}$, Claus Belka ${ }^{1,3}$, Verena Jendrossek ${ }^{1,4}$

${ }^{1}$ University of Tübingen, Department of Radiation Oncology, Hoppe-Seyler-Str. 3, 72076

Tübingen, Germany

${ }^{2}$ current address: Rockefeller University, 1230 York Ave, New York, NY 10065

${ }^{3}$ Department of Radiation Oncology, Ludwig-Maximilian Universität Munich,

Marchioninistr. 15, 81377 Munich, Germany

${ }^{4}$ Institute for Cell Biology (Cancer Research), Department of Molecular Cell Biology, University of Duisburg-Essen Medical School, Virchowstrasse 173, 45122 Essen, Germany

Scientific category: Neoplasia

\section{Corresponding author:}

Prof. Dr. Verena Jendrossek, University of Duisburg-Essen, Medical School, Institute for Cell Biology (Cancer Research), Virchowstr. 173, 45122 Essen, Germany

E-mail: verena.jendrossek@uni-due.de, Phone: +49-201-7233380; Fax: +49-201-7235904

\section{Short running title:}

Mcl-1 and Noxa in Celecoxib-induced apoptosis

Word count abstract: 181

Word count text: 5019

Number of figures: 6

Number of tables: 0

Number of references: 50 


\begin{abstract}
:
The cyclooxygenase- 2 inhibitor Celecoxib is a potent inducer of apoptosis in tumor cells. In most cellular systems Celecoxib induces apoptosis via an intrinsic, mitochondrial apoptosis pathway. We recently showed that in Bax-negative Jurkat cells expression of pro-apoptotic Bak is essential for Celecoxib-induced mitochondrial damage and apoptosis induction. Aim of the present study was to identify specific pro- and anti-apoptotic members of the Bcl-2 family involved in the regulation of Bak activation, and subsequent apoptosis upon treatment with Celecoxib in the Jurkat cell model.

Our results show that apoptosis in response to Celecoxib required the presence of Noxa and downregulation of the anti-apoptotic protein Mcl-1. Celecoxib-induced Bak activation and subsequent apoptosis could be inhibited by overexpression of $\mathrm{Bcl}-\mathrm{xL}$ but not by the very similar Bcl-2. In Bcl-xL-overexpressing cells neutralization of both, Mcl-1 and Bcl-xL, was prerequisite for an efficient induction of apoptosis. Our data reveal an important role of the Mcl-1/Noxa axis for Celecoxib-induced apoptosis and suggest that Celecoxib may be of value for treatment of tumors addicted to Mcl-1 and for combined treatment approaches targeting anti-apoptotic Bcl-2 family members.
\end{abstract}




\section{Introduction:}

Malignant transformation of cells is characterized by the accumulation of mutations that allow the tumor cells to circumvent growth constraints, inter alia by acquisition of apoptosis resistance. Stress situation like hypoxia, DNA damage, growth factor withdrawal, and chemotherapeutic agents initiate the intrinsic apoptotic pathway which ultimately results in the release of cytochrome $\mathrm{C}$ from the mitochondria into the cytosol where caspases become activated to execute apoptosis [1-4].

Members of the Bcl-2 protein family which act at the mitochondrial level regulating mitochondrial homeostasis and permeability are important modulators of the intrinsic apoptotic pathway and other events, e.g. autophagy and necrosis [5-7]. The Bcl-2 protein family consists of various pro- and anti-apoptotic members that form heterodimers in order to inhibit or activate each other. The anti-apoptotic members comprise the well-known proteins Bcl-2 and Bcl-xL as well as Bcl-w, Mcl-1, A1, and Boo/Diva and are often upregulated in tumors. The pro-apoptotic members include the multi-domain proteins Bak, Bax, and Bok, and the very heterogeneous group of so-called "BH3-only proteins" (Bid, Bim Bad, Bmf, Bik, Hrk, Noxa) that have only one small stretch of amino acids in common and are suggested to constitute intracellular sensors of cellular stress.

Activation of the multidomain proteins Bax or Bak or even both is absolutely required for the initiation of the intrinsic apoptotic pathway. Currently two main models have been proposed to explain how Bcl-2 members might promote mitochondrial permeabilization and subsequent apoptosis. The displacement model or indirect activation model is based on the notion that anti-apoptotic Bcl-2 proteins directly interact with Bax and Bak to suppress their activation in healthy cells $[5,6,8]$. In response to apoptotic stimuli, specific $\mathrm{BH}$-only proteins become activated, bind to their respective anti-apoptotic counterparts, and displace them from their interaction with Bax and Bak. Unbound Bax and Bak undergo spontaneous selfoligomerization facilitating the breakdown of the mitochondrial membrane potential $(\Delta \Psi \mathrm{m})$, cytochrome $\mathrm{C}$ release into the cytosol, caspase-activation, and finally apoptosis.

In contrast, the direct activation model subdivides the BH-3 only proteins into so-called "sensitizers" (Bad, Bmf, Bik, Hrk, Noxa) that bind to anti-apoptotic Bcl-2 family members and the "activators" (t-Bid, Bim, Puma) that are suggested to bind directly to the proapoptotic multi-domain proteins Bax and Bak thereby triggering their activation. This model is supported by the observation that $\mathrm{tBid}$, Bim, and possibly also Puma are required to activate Bax and Bak in order to induce apoptosis [9-12]. In healthy cells the anti-apoptotic Bcl-2 proteins keep the activator BH3-only proteins in check unless apoptotic stimuli lead to the 
accumulation of active sensitizer $\mathrm{BH} 3$-only proteins that displace the activator $\mathrm{BH} 3$-only proteins from their binding partners which then bind to and activate Bax and/or Bak.

Although initial publications suggested a redundant role for the members of the three main groups of Bcl-2 proteins, recent results implicate that particularly $\mathrm{BH} 3$-only proteins may be regulated by specific cellular stress signals. Moreover, protein interaction studies have shown that certain BH3-only proteins favor the interaction with specific anti-apoptotic family members supporting the hypothesis of non-redundant but specific action of the BH3-only protein members $[6,13]$.

The non-steroidal anti-inflammatory drug Celecoxib is known as a specific inhibitor of cyclooxygenase-2 (COX-2). Surprisingly, Celecoxib and its derivates turned out to exert promising anti-neoplastic effects that may be exploited in cancer prevention and treatment [14]. Cyclooxygenases catalyze the conversion of arachidonic acid into prostaglandins and are major players during the process of inflammation [15]. COX-2 overexpression is observed in many human tumors and contributes to tumorigenesis and therapy resistance. Therefore, the anti-neoplastic activity of Celecoxib had first been related to its inhibitory action on COX-2. Recent experiments in COX-2 negative cell lines, however, showed that Celecoxib is able to inhibit proliferation and induce apoptosis in a COX-2-independent manner. This observation was corroborated by similar findings in experiments performed with cells in which COX-2 was knocked down by siRNA or by the use of Celecoxib derivatives without COX-2 inhibitory action [16-19].

We and others have shown earlier that Celecoxib induced apoptosis through activation of an intrinsic pathway that was not blocked by overexpression of Bcl-2 [20-23]. Moreover, we recently demonstrated that in Bax-deficient Jurkat cells Bak was essential for Celecoxibinduced apoptosis [17]. Aim of the present investigation was to specify pro- and antiapoptotic members of the Bcl-2 family involved in Bak activation, mitochondrial damage and apoptosis upon treatment with Celecoxib in the Jurkat cell model with a focus on Mcl-1 and $\mathrm{Bcl}-\mathrm{xL}$ as central regulators of Bak activation.

We show that Bak-dependent apoptosis in response to treatment with Celecoxib involved rapid downregulation of Mcl-1 and required the expression of the Mcl-1-interacting BH3-only protein Noxa. Celecoxib-induced apoptosis was blocked by overexpression of Bcl-xL. Although silencing of Mcl-1 was sufficient to induce apoptosis in Jurkat Vector cells it had only a minor sensitizing effect when Bcl-xL or Bcl-2 were overexpressed. In Bcl-xL overexpressing cells both, Mcl-1 and Bcl-xL, had to be neutralized for successful induction of 
apoptosis. Our novel results clearly demonstrate that Celecoxib induces apoptosis in Jurkat cells via the Mcl-1/Noxa axis and can be inhibited by overexpression of Bcl-xL.

The prominent Mcl-1-antagonizing effects recommend to use Celecoxib in innovative single drug treatment of apoptosis-resistant tumors that depend on Mcl-1 for survival or in combinatory treatment, e.g. with Bad-like BH3-only-mimetic ABT-737, in tumors that express multiple anti-apoptotic Bcl-2 family members. 


\section{Material and methods:}

\subsection{Reagents and antibodies}

All chemicals were purchased from Sigma (Deisenhofen, Germany) unless otherwise specified.

For Western blotting following antibodies were used: polyclonal antibodies against caspase-3, PARP, Mcl-1, Bcl-xL, and $\alpha / \beta$-Tubulin were obtained from Cell Signaling (NEB Frankfurt, Germany). The monoclonal antibody against Bcl-2 from Santa Cruz Biotechnology (clone 100, Heidelberg, Germany), the monoclonal caspase- 9 antibody and the polyclonal Bak antibody from Upstate (Millipore, Schwalbach, Germany). COX-2 and cytochrome C (clone 7H8.2C12) monoclonal antibodies were obtained from Transduction Labs (Becton Dickinson, Heidelberg, Germany). Noxa monoclonal antibody was purchased from Calbiochem (Merck, Nottingham, UK). The monoclonal antibody against $\beta$-Actin was obtained from Sigma (Deisenhofen, Germany), the monoclonal antibody against GAPDH from Abcam (Cambridge, UK). Horseradish peroxidase (HRP)-conjugated secondary antibodies were purchased from GE Healthcare/Amersham Biosciences (Freiburg, Germany).

Bak activation was determined using the activation-specific antibody from Calbiochem (Merck, Nottingham, UK) or the matched IgG control from Santa Cruz Biotechnology, Heidelberg, Germany) in combination with Alexa488-coupled anti-mouse antibody from Molecular Probes (Invitrogen, Karlsruhe, Germany).

Immunoprecipitation was performed with a monoclonal antibody against Mcl-1 (Becton Dickinson, Heidelberg, Germany) or Noxa (Calbiochem/Merck, Nottingham, UK).

The pan-caspase inhibitor zVAD-fmk was purchased from Bachem (Bubendorf, Suisse).

Celecoxib was kindly provided by Pharmacia-Pfizer (Erlangen, Germany).

\subsection{Cells and cell culture}

Jurkat E6 T-lymphoma cells were from ATCC (Bethesda, Maryland, USA). Jurkat cells stably expressing $\mathrm{Bcl}-\mathrm{xL}$ or $\mathrm{Bcl}-2$ and the respective Vector control were prepared as described before [1, 24].

Cells were grown in RPMI 1640 medium supplemented with 10\% fetal calf serum (Gibco Life Technologies, Eggenstein, Germany) and maintained in a humidified incubator at $37^{\circ} \mathrm{C}$ and $5 \% \mathrm{CO}_{2}$. 


\subsection{Transfection with siRNA}

Cells were cultured at a low density to ensure log phase growth. For transfection $2 \times 10^{6}$ cells were resuspended in $200 \mu \mathrm{L}$ RPMI-1640 without phenol red. Shortly before transfection mcl1, bcl-x, or non-targeting siRNA was added at indicated concentration. mcl-1 ON-TARGET SMARTpool and the siCONTROL NON-TARGETING pool siRNA was purchased from Dharmacon (Chicago, IL, USA), bcl-x silencer ${ }^{\circledR}$ Select pre-designed siRNA was from Ambion (Applied Biosystems, Austin, Texas, USA). Cells were electroporated in a $4 \mathrm{~mm}$ cuvette in an EPI2500 electroporator (Fischer, Heidelberg, Germany) at $370 \mathrm{~V}$ for $10 \mathrm{msec}$. Immediately after transfection cells were resuspended in $6 \mathrm{~mL}$ prewarmed medium and continued to be cultured as described above. Transfection efficiency and viability was determined by transfecting the cells with $400 \mathrm{nM}$ green fluorescence siRNA (siGLO from Dharmacon, Chicago, IL, USA) followed by propidium iodide exclusion dye and flow cytometric analysis.

\subsection{Determination of apoptosis and necrosis by fluorescence microscopy}

Morphological changes during apoptosis like chromatin condensation and permeability of the plasma membrane were analyzed by fluorescence microscopy after co-staining the cells with $1.5 \mu \mathrm{M}$ Hoechst 33342 (Calbiochem, Merck, Nottingham, UK) and $2.5 \mu \mathrm{g} / \mathrm{mL}$ propidium iodide using the fluorescence microscope Axiovert 200 from Zeiss with a G365/FT395/LP420 filter set (Carl Zeiss, Jena, Germany). The morphological changes were documented using the CCD camera device Zeiss Axiocam MR. 3 different people counted 100 cells each using different fields. Diffuse blue DNA staining was indicative for healthy cells, blue condensed DNA staining for early apoptotic, red condensed DNA staining for late apoptotic, and red diffuse staining for necrotic cells.

\subsection{Flow cytometric analysis}

The mitochondrial membrane potential $(\Delta \Psi \mathrm{m})$ was analyzed using the $\Delta \Psi \mathrm{m}$ specific dye TMRE (Molecular Probes, Mobitech, Goettingen, Germany). At the indicated time points $10^{5}$ cells were stained for $30 \mathrm{~min}$ in PBS containing $25 \mathrm{nM}$ TMRE. Co-incubation with $1 \mu \mathrm{M}$ of the cyanide derivate CCCP was used as a positive control to complete the mitochondrial depolarisation.

Nuclear fragmentation was determined after staining the cells with $5 \mu \mathrm{g} / \mathrm{mL}$ propidium iodide in a hypotonic buffer containing $0.1 \%$ sodium citrate and $0.1 \%$ Triton $\mathrm{X}-100$ for $1 \mathrm{~h}$ at room temperature. 
Activation of Bak was detected employing antibody that recognizes the active form of Bak (mouse monoclonal antibody from Calbiochem/Merck, Nottingham, UK). In brief, $10^{6}$ cells were fixed with $2.5 \%$ PFA for 20 min at $4^{\circ} \mathrm{C}$. After permeabilization with $50 \mu \mathrm{g} / \mathrm{mL}$ Digitonin, cells were incubated with the Bak antibody or isotype matched control IgGs at a concentration of $0.5 \mu \mathrm{g} / \mathrm{mL}$ for $45 \mathrm{~min}$ at room temperature. After washing them once, the cells were incubated with a secondary antibody that was coupled to the fluorophore Alexa488 (1:1000 dilution, Molecular Probes/Invitrogen, Karlsruhe, Germany) for additional 45 min at room temperature $45 \mathrm{~min}$.

Cells stained with TMRE or propidium iodide were analysed in channel 2, Bak activation was analysed in channel 1 employing a FACS Calibur flow cytometer and the Cell Quest software from Becton Dickinson (Heidelberg, Germany).

\subsection{Western blot analysis}

$2 \times 10^{6}$ cells were lysed in $200 \mu \mathrm{L}$ lysis buffer containing $50 \mathrm{mM}$ HEPES pH7.5, $150 \mathrm{mM}$ $\mathrm{NaCl}, 1 \%$ CHAPS, $1 \mathrm{mM}$ EDTA, $10 \mathrm{mM}$ sodium pyrophosphate, $10 \mathrm{mM} \mathrm{NaF}, 2 \mathrm{mM}$ $\mathrm{Na}_{3} \mathrm{VO}_{4}, 100 \mathrm{mM}$ PMSF, $5 \mu \mathrm{g} / \mathrm{mL}$ Aprotinin, $5 \mu \mathrm{g} / \mathrm{mL}$ Leupeptin, and $3 \mu \mathrm{g} / \mathrm{mL}$ Pepstatin. After removing insoluble material by centrifugation for $10 \mathrm{~min}$ at $13000 \mathrm{rpm}$, the protein concentration was estimated in the supernatant using the Bio-Rad protein assay (Bio-Rad, Munich, Germany) according to the manufacturer's protocol. Protein was separated by SDSPAGE under reducing conditions before transfer onto PVDF membranes (Roth, Karlsruhe, Germany). Blots were blocked in TBS buffer containing 0.05\% Tween 20 and 5\% non-fat dry milk for $1 \mathrm{~h}$ at room temperature. The membrane was incubated overnight at $4^{\circ} \mathrm{C}$ with the respective primary antibodies. After repeated washings with TBS/Tween-20 $(0.05 \%)$ the membranes were incubated with the secondary antibody for $1 \mathrm{~h}$ at room temperature before continuing to wash with TBS/Tween-20 (0,05\%). Detection of antibody binding was performed by enhanced chemoluminescence (ECL Western blotting analysis system, GE Healthcare/Amersham-Biosciences, Freiburg, Germany).

All Western blot experiments were repeated at least twice.

\subsection{Cytochrome c release}

$13 \times 10^{6}$ cells were resuspended in $200 \mu \mathrm{L}$ buffer containg $250 \mathrm{mM}$ sucrose, $20 \mathrm{mM}$ HEPES, pH 7.4, $10 \mathrm{mM} \mathrm{KCl}, 1.5 \mathrm{mM} \mathrm{MgCl}_{2}, 1$ mM EGTA, 1 mM DTT, $100 \mu \mathrm{M}$ PMSF, $5 \mu \mathrm{g} / \mathrm{mL}$ Aprotinin and Leupeptin, and $3 \mu \mathrm{g} / \mathrm{mL}$ Pepstatin. The cells were homogenized with 25 strokes employing the Wheaton homogenizer before centrifugation for $45 \mathrm{~min}$ at $13000 \mathrm{rpm}$ 
and $4^{\circ} \mathrm{C} .30 \mu \mathrm{L}$ of the supernatant was separated by SDS gel electrophoresis before detection of cytochrome $\mathrm{C}$ by Western blot as described above. Equivalent homogenisation and loading on the gel was verified by detection of GAPDH.

\subsection{Immunoprecipitation}

Cells were lysed as described above. The protein concentration was adjusted to $1 \mathrm{mg} / \mathrm{mL}$. $5 \mu \mathrm{g}$ antibody and $50 \mu \mathrm{L}$ slurry Dynabeads ${ }^{\circledR}$ suspension (Dynal/Invitrogen, Karlsruhe, Germany) were added to $500 \mu \mathrm{L}$ lysate. After the precipitation for $3 \mathrm{~h}$ at $4{ }^{\circ} \mathrm{C}$ the beads were washed thrice with $300 \mu \mathrm{L}$ lysis buffer containing 0.2\% CHAPS. Proteins were eluted by boiling the beads for $5 \mathrm{~min}$ in $100 \mu \mathrm{L}$ SDS sample buffer with $\beta$-Mercaptoethanol. $30 \mu \mathrm{L}$ were separated by SDS gel electrophoresis before detection by Western blotting as described above. 


\section{Results:}

\subsection{Celecoxib-induced apoptosis involves activation of Bak}

Our earlier data revealed that in Jurkat T-lymphoma cell lines pro-apoptotic Bak was required for apoptosis induction in response to treatment with Celecoxib [17]. To verify proper function of the Jurkat T-lymphoma E6.1 cell model used in the present study, we first examined extent and time course of apoptosis induction as well as activation of Bak after short term treatment with 50-100 $\mu \mathrm{M}$ Celecoxib (Fig. 1). Celecoxib induced time- and concentration-dependent apoptosis in Jurkat E6.1 cells. As determined by flow cytometric analysis, the breakdown of the mitochondrial membrane potential $(\Delta \Psi \mathrm{m})$ was observed already $3 \mathrm{~h}$ and DNA fragmentation $6 \mathrm{~h}$ after treatment with Celecoxib (Fig. 1A). Similar to our earlier findings, treatment with $50 \mu \mathrm{M}$ Celecoxib was sufficient for cell death induction, but apoptosis was more pronounced when drug concentrations of $75 \mu \mathrm{M}$ or $100 \mu \mathrm{M}$ were used (Fig. 1A). Our data were corroborated by Western blot analyses revealing substantial concentration-dependent cleavage of caspase-9, caspase-3, and the caspase-3 substrate PARP already $3 \mathrm{~h}$ after treatment with $50-100 \mu \mathrm{M}$ Celecoxib (Fig. 1B). Apoptosis in Jurkat T cells was COX-2-indpendent since those cells did not express COX-2. An unspecific induction of COX-2 expression during treatment was also excluded (Fig. 1C).

To further establish the importance of Bak for Celecoxib-induced apoptosis, we next verified whether treatment with Celecoxib would trigger activation-associated changes in the conformation of Bak by flow cytometry. Using an antibody which recognizes the active conformation of Bak we detected a fluorescence shift by flow cytometric analysis $6 \mathrm{~h}$ after treatment with $75 \mu \mathrm{M}$ and $100 \mu \mathrm{M}$ Celecoxib (Fig. 1D). Treatment of the cells with the pancaspase inhibitor $\mathrm{zVAD}$ before exposure to $75 \mu \mathrm{M}$ Celecoxib did not abolish the activation of Bak (Fig. 1E). Neither was $\Delta \Psi \mathrm{m}$ breakdown affected by treatment with zVAD (Fig. 1F) indicating that Bak activation and mitochondrial permeabilization occur upstream of caspase activation.

\subsection{Celecoxib signals through the Mcl-1/Noxa axis}

Activation of the multidomain proteins Bak or Bax or even both is absolutely required for the initiation of mitochondrial permeabilization, a key event in the intrinsic apoptosis pathway. Therefore, we next aimed to specify the role of pro- and anti-apoptotic members of the Bcl-2 family involved in the activation of Bak, mitochondrial damage and apoptosis upon treatment with Celecoxib. Since our earlier data indicated an influence of Celecoxib on Mcl-1 protein levels we first examined to what extent Mcl-1 was involved in apoptosis regulation in 
response to treatment with Celecoxib. As shown in Fig. 2A, Celecoxib triggered a concentration-dependent decrease in Mcl-1 protein levels. Whereas Mcl-1 protein levels were largely decreased $6 \mathrm{~h}$ after treatment with $50 \mu \mathrm{M}$ Celecoxib, Mcl-1 was no longer detectable when cells were treated at higher drug concentrations. In contrast, levels of other proapoptotic Bak and the BH3-only Noxa remained unchanged during treatment (Fig. 2A). In a functional approach we subsequently examined whether downregulation of Mcl-1 affects survival of Jurkat E6.1 cells. To this end, Mcl-1 expression was decreased by siRNAmediated silencing. As shown in Fig. 2B, Mcl-1 expression was clearly downregulated $6 \mathrm{~h}$ after electroporation. Interestingly, electroporation of $10 \mathrm{nM}$ mcl-1 siRNA was sufficient to downregulate Mcl-1 (Fig. 2B) and induce $\Delta \Psi \mathrm{m}$ breakdown (Fig. 2D), caspase activation (Fig. 2B) and DNA degradation (Fig. 2C). The effects were even more pronounced when higher concentrations of mcl-1 siRNA were used. In contrast, non-targeting siRNA (nt) did not show any effects except for a little background apoptosis due to the transfection procedure (data not shown). These data show undoubtedly, that the downregulation of Mcl-1 is sufficient for the initiation of apoptosis in Jurkat E6.1 and, hence, seems to be critical during Celecoxibinduced apoptosis.

Recent investigations suggest that the pro-apoptotic Noxa, a BH3-only protein with binding preferences for Mcl-1 and A1, may be essential for neutralization and/or degradation of Mcl-1 (Czabotar et al., 2007; Nijhawan et al., 2003; Willis and Adams, 2005). We therefore tested how far treatment with Celecoxib affects expression of Noxa or its binding to Mcl-1. Noxa levels remained however unchanged in response to Celecoxib treatment (Fig. 2A). The analysis of the interaction between Noxa and Mcl-1 by immunoprecipitation studies clearly shows an interaction of Mcl-1 with Noxa in healthy, untreated cells (Fig. 3A). Binding of Noxa to Mcl-1 was greatly reduced $6 \mathrm{~h}$ after treatment with $75 \mu \mathrm{M}$ Celecoxib, obviously due to the rapid decrease of Mcl-1 protein levels.

For a better understanding of Noxa`s role during Celecoxib-induced apoptosis, we examined whether siRNA-mediated silencing of Noxa expression would affect Celecoxib-induced apoptosis. Transfection of Jurkat E6.1 cells with $500 \mathrm{nM}$ of noxa siRNA led to a substantial decrease in Noxa protein levels without affecting Mcl-1 expression (Fig. 3B). Transfection with noxa siRNA alone did not affect survival of Jurkat E6.1 cells (Fig. 3C). However, when treated with $75 \mu \mathrm{M}$ Celecoxib, sensitivity of Jurkat E6.1 cells to Celecoxib-induced apoptosis was significantly reduced by Noxa silencing as measured by DNA fragmentation (Fig. 3D). These data reveal for the first time that Noxa functions as a central mediator of Celecoxibinduced apoptosis. 
Furthermore, silencing of Noxa did not change the sensitivity of Jurkat cells towards apoptosis induction by mcl-1 siRNA (Fig. 3E) suggesting that Mcl-1 acts downstream of Noxa in the apoptotic pathway. In addition, the latter experiment indicates that not free Noxa released from its interaction with Mcl-1 is important for Celecoxib-induced apoptosis but rather the neutralization of Mcl-1.

\subsection{Overexpression of Bcl-xL but not Bcl-2 interferes with Celecoxib-induced apoptosis in}

\section{Jurkat Tlymphoma cells}

Up to now our data pointed to a central role of the Mcl-1/Noxa axis for Bak-dependent apoptosis induction in response to treatment with Celecoxib. However, previous publications suggested that, apart from Mcl-1, Bcl-xL is an additional factor controlling Bak activation.

To clarify a putative role of $\mathrm{Bcl}-\mathrm{xL}$ and $\mathrm{Bcl}-2$ in the regulation of Bak-dependent apoptosis, Jurkat E6.1 cells stably overexpressing either Bcl-2 or Bcl-xL were employed. Both Bcl-2 and Bcl-xL overexpressing cells expressed similar levels of Mcl-1 and Bak compared to the Vector control cells, and none of them expressed COX-2 (Fig. 4A). Fluorescence microscopic evaluation of cell death induction upon double staining with Hoechst 33342 and propidium iodide showed that Celecoxib induces apoptosis with similar efficiency in Bcl-2 overexpressing and Vector control cells (Fig. 4B). The double staining also revealed that most of the cells died indeed by apoptosis. A shift towards necrotic cell death could not be detected in Bcl-2 overexpressing cells.

Bcl-xL overexpression, however, was very protective against Celecoxib-induced cell death. Consistent with these data, Bcl-xL overexpression also suppressed Bak activation (Fig. 4E), release of cytochrome $\mathrm{C}$ into the cytosol (Fig. 4F), $\Delta \Psi \mathrm{m}$ breakdown (Fig. 4C), as well as processing of caspase-9, caspase-3, and PARP cleavage (Fig. 4D) in response to Celecoxib, whereas overexpression of the very similar Bcl-2 hardly affected any of these events. Interestingly, despite its strong protective effects against the cytotoxic action of Celecoxib, Bcl-xL did not prevent the downregulation of Mcl-1.

For a better understanding of Mcl-1, Bcl-2, and Bcl-xL during Celecoxib-induced apoptosis, Mcl-1 expression was downregulated in Bcl-xL- and Bcl-2-overexpressing cells by siRNAmediated silencing. Jurkat Vector cells transfected with mcl-1 siRNA were used as a control. Silencing of Mcl-1 was not sufficient to induce $\Delta \Psi \mathrm{m}$ breakdown and DNA degradation in the presence of high Bcl-xL levels (Fig. 5A upper and lower panel). Accordingly, a strong processing of caspase-3 and PARP was only observed in Jurkat Vector cells whereas only 
minor caspase-3 and PARP-cleavage was observed in Bcl-xL overexpressing cells after silencing with mcl-1 siRNA (Fig. 5B).

Surprisingly, Bcl-2 overexpression was sufficient to inhibit the induction of $\Delta \Psi \mathrm{m}$ breakdown, caspase activation and apoptosis in response to siRNA-mediated Mcl-1 silencing (Fig. 5A upper and lower panel; Fig 5B) suggesting that treatment with Celecoxib triggers not only downregulation of Mcl-1 protein levels but additional pro-apoptotic signaling events leading to neutralization of Bcl-2.

To test the hypothesis, we examined in the following experiment whether siRNA-mediated silencing of Mcl-1 affects the cellular response of Jurkat Vector, Bcl-2- or Bcl-xLoverexpressing cells to the cytotoxic action of Celecoxib. To this end, the cells were subjected to siRNA-mediated Mcl-1 silencing and subsequently treated with $75 \mu \mathrm{M}$ Celecoxib. Downregulation of Mcl-1 slightly increased Celecoxib-induced mitochondrial permeabilization and DNA-fragmentation in Bcl-2- as well as in Bcl-xL-overexpressing cells (Fig. 5C). However, only Bcl-2 overexpressing cells displayed high apoptotic rates in response to Celecoxib-treatment in the presence and absence of Mcl-1. In contrast, Bcl-xL overexpressing cells remained very resistant to Celecoxib-induced apoptosis also in the absence of Mcl-1 (Fig. 5C).

\subsection{Neutralization of both Mcl-1 and Bcl-xL is neccessary for successful induction of} apoptosis in Bcl-xL overexpressing Jurkat cells

Up to now our data indicated that although overexpression of Bcl-2 or Bcl-xL protected Jurkat cells efficiently from apoptosis induction by siRNA-mediated Mcl-1 silencing, only Bcl-xL overexpression protected from mitochondrial damage and nuclear fragmentation induced by Celecoxib. Therefore, in a last set of experiments, it remained to be determined whether silencing of Bcl-xL would render the Bcl-xL overexpressing cells sensitive to treatment with Celecoxib again. To this end, Bcl-xL overexpressing and Vector control cells were transfected with bcl-x siRNA before analyzing DNA fragmentation (Fig. 6A). Although silencing of Bcl-xL itself slightly induced apoptosis in Jurkat Vector cells within $72 \mathrm{~h}$ after electroporation, the apoptotic rates never reached those obtained in response to Mcl-1 silencing (Fig. 6A, upper panel). In Bcl-xL overexpressing Jurkat cells, Bcl-xL expression was clearly downregulated already $24 \mathrm{~h}$ after electroporation (Fig. 6B). Nevertheless, silencing of Bcl-xL did not induce apoptosis on its own (Fig. 6A, lower panel). However, silencing of $\mathrm{Bcl}-\mathrm{xL}$ restores the sensitivity towards apoptosis induced by Celecoxib (Fig. 6C). In an additional experiment, $48 \mathrm{~h}$ after first electroporation with bcl-x siRNA (1st EP), the cells 
were electroporated a second time with mcl-1 siRNA or the non-targeting control siRNA (2nd EP). Consistently, siRNA-mediated Mcl-1 silencing induced $\Delta \Psi \mathrm{m}$ breakdown and apoptosis in Bcl-xL-silenced cells (Fig. 6E). Successful downregulation of appropriate proteins was verified by Western blotting (Fig. 6D and F). We conclude that, in Bcl-xL overexpressing cells, the execution of apoptosis by Celecoxib or Mcl-1 silencing is only possible when both, Mcl-1 and Bcl-xL are neutralized. 


\section{Discussion:}

Apart from its anti-inflammatory action, the selective COX-2 inhibitor Celecoxib exerts potent anti-tumor effects. Consequently, the drug found application in cancer prevention in patients with familial adenomatous polyposis. Here, we showed that Celecoxib effectively induces apoptosis in Bax-deficient COX-2-negative Jurkat T lymphoma cells. Moreover, we demonstrate for the first time that Celecoxib-induced apoptosis involves the Mcl-1/Noxa axis and can be efficiently blocked by overexpression of Bcl-xL but not the similar Bcl-2. In our hands survival of Jurkat cells depended on Mcl-1 expression, since downregulation of Mcl-1 by siRNA was sufficient to induce apoptosis, an observation that corroborates earlier findings [25, 26, 27]. Consequently, Celecoxib-mediated downregulation of Mcl-1 would result in the release of these BH3-only activator proteins from Mcl-1 and subsequent Bakactivation.

We also demonstrate that in untreated Jurkat cells Mcl-1 interacts with the BH3-only protein Noxa. The loading of anti-apoptotic Bcl-2 family members with pro-apoptotic BH3-only proteins suggest a cellular state described as "primed to death" $[6,13]$. Coimmunoprecipitation studies revealed that this interaction is abrogated during Celecoxibinduced apoptosis due to the downregulation of Mcl-1. Interestingly, RNAi-mediated silencing of Noxa clearly inhibited Celecoxib-induced apoptosis indicating a major role of Noxa during Celecoxib-induced apoptosis. A similar involvement of the Mcl-1/Noxa axis in apoptosis induction has been shown for further chemotherapeutic agents including camptothecin, the cyclin-dependent kinase inhibitor Seliciclib, the proteasome inhibitor bortezomib, histone deacetylsae inhibitors, arsenic trioxide, and glucose withdrawal [28-33]. The BH3-only protein Noxa belongs to the group of sensitizers that do not activate Bax or Bak by a direct interaction. It preferentially binds to Mcl-1 and A1, but not to Bcl-2 or Bcl$\mathrm{xL}$, to neutralize their anti-apoptotic effects [13]. In addition, Noxa might also regulate Mcl-1 protein stability $[34,35]$ since Noxa expression inversely correlated with Mcl-1 protein levels in some studies $[36,37]$. In contrast, in our cell system, silencing of Noxa did not increase Mcl-1 expression levels arguing against a role of Noxa for Mcl-1 degradation in our system. Furthermore, it seems that binding of Noxa is not sufficient to induce apoptosis suggesting an additional signal that facilitates Mcl-1 downregulation and successive apoptosis.

\subsection{Effects of $B c l-x L$ and $B c l-2$}

In cells overexpressing Bcl-2 or Bcl-xL RNAi-mediated downregulation of Mcl-1 was no longer sufficient to efficiently trigger apoptosis. Thus, Bcl-2 and Bcl-xL can substitute for 
Mcl-1 and also maintain survival in untreated Jurkat cells when survival-promoting Mcl-1 is down-regulated, since $\mathrm{Bcl}-2$ and $\mathrm{Bcl}-\mathrm{xL}$ bind to and neutralize pro-apoptotic BH3-only proteins Bim, tBid, or Puma as efficiently as Mcl-1 $[6,13]$. Those results corroborate earlier observations on a redundant function of pro- and anti-apoptotic Bcl-2 family members and also support the assumption that in a given cell type, all anti-apoptotic Bcl-2 family members have to become neutralized for efficient induction of apoptosis.

Subsequent analysis of Celecoxib-induced apoptosis revealed a protective effect by overexpression of the anti-apoptotic Bcl-xL. Although Bcl-xL could inhibit Bak activation and following apoptotic downstream events, it was not able to prevent Mcl-1 downregulation putting Mcl-1 upstream of Bcl-xL or in two independent pathways.

Interestingly, siRNA-mediated silencing of Bcl-xL in Jurkat Vector control cells was not as efficient in apoptosis induction as siRNA-mediated downregulation of Mcl-1 emphasizing again the dependence of Jurkat cells on Mcl-1 for survival. However, RNAi-mediated downregulation of Bcl-xL in Bcl-xL-overexpressing cells sensitized towards Celecoxibinduced apoptosis. In addition, the silencing experiments demonstrated that in Bcl-xL overexpressing cells, neutralization of both, Bcl-xL and Mcl-1, is important for a successful therapy.

In contrast to Bcl-xL, overexpression of the very similar Bcl-2 did not prevent Celecoxibinduced Bak activation and apoptosis although Bcl-2 overexpression could compensates for loss of Mcl-1. These findings suggest that in addition to its Mcl-1-antagonistic effects, Celecoxib must induce further pro-apoptotic signaling events that are sufficient to neutralize anti-apoptotic effects of Bcl-2 but not of Bcl-xL. The molecular details of the effects that specifically lead to the neutralization of Bcl-2 but not those of Bcl-xL remain to be defined. It may be speculated that Celecoxib induces a post-translational modification of Bcl-2 that regulates its anti-apoptotic function whereas Bcl-xL remains unaffected. Alternatively, Bcl-xL and Bcl-2 may function differentially to prevent Bak activation. In this regard, an earlier study demonstrated high affinity binding of Bcl-xL to peptides derived from Bax and Bak with an approximately 40-fold higher binding preference for the latter [38]. Unfortunately, such an extensive binding study does not exist for Bcl-2. Recent studies, however, demonstrated that although Bcl-2 might be co-precipitated with Bax and Bak in some overexpressing cell systems, its protective role differs from Bcl-xL in vivo [37, 39, 40]. For instance, Zhai et al. showed that Bcl-2 protected better from apoptosis induced by Bax rather than by Bak hinting at a inhibitory effect through Bcl-2:Bax interaction. On the other hand, Willis et al. detected 
an interaction of Bak with Bcl-xL and Mcl-1 only but not with Bcl-2 in co-precipitation studies concluding that Bcl-xL protects from apoptosis through sequestration of Bak. Jurkat cells do not express Bax excluding an inhibitory effect on Celecoxib-induced apoptosis through direct interaction of Bcl-2 with Bax [17]. However, Jurkat cells express Bak, and Bcl$\mathrm{xL}$, when overexpressed, can bind to Bak preventing its activation and mitochondrial permeabilization. Yet, Bcl-2 as well as Bcl-xL and Mcl-1 might sequester pro-apoptotic BH3only proteins like Bim or tBid impeding those proteins from their interaction with Bak. A direct activation of Bak and Bax by the BH3-only protein Bim was proposed by several groups $[9,11]$. Since overexpression of Bcl-2 hardly affected Celecoxib-induced apoptosis, the sequestration of $\mathrm{BH} 3$-only Bim or tBid by anti-apoptotic proteins seems to be of minor importance. We, therefore, favor the indirect activation model in our Jurkat cell system as described earlier [8, 13, 37, 39]. In this scenario, Bcl-xL would exert its protection through interaction with Bak. Binding of $\mathrm{BH} 3$-only proteins to $\mathrm{Bcl}-\mathrm{xL}$ would be required to displace Bak from Bcl-xL to allow its activation. However, additional Celecoxib-dependent mechanisms could not be excluded. The activation of other BH3-only proteins acting directly on Bcl-xL and Bak is likely, but further experiments are needed to identify putative regulators.

\subsection{Therapeutic opportunities}

Considering the displacement model, two independent pathways employing different Bcl-2 family members have been established during last couple of years: one that involves Mcl-1 and A1 and can be neutralized by Noxa, and another that leads to activation of the BH3-only Bad which antagonizes Bcl-2, Bcl-xL, and Bcl-w [13, 41]. Triggering of both pathways at the same time would result in enhanced Bak activation, mitochondrial permeabilization, and caspase activation. Synergistic activation of the Noxa/Mcl-1 and Bad/Bcl-xL pathways is mimicked by using the relatively unspecific BH3-mimetic obatoclax (GX15-070) targeting both pathways at the same time [42]. However, enhanced apoptosis was also observed, when the Bad-mimetic ABT-737 was combined with bortezomib, homoharringtonine, N-(4hydroxy-phenyl)retinamid, Sorafenib, Carboplatin, or TRAIL [43-48]. Since ABT-737 targets only Bcl-2, Bcl-xL, and Bcl-w, the former mentioned drugs probably activate the Noxa/Mcl-1 pathway. This underlines the importance to activate both, the Noxa/Mcl-1 and the Bad/Bcl-xL pathways to effectively remove precarious tumor cells. Based on this assumption the Mcl-1 antagonistic effects of Celecoxib suggest that the drug may also be effective in sensitizing 
cells with overexpression of Bcl-2 family members to apoptosis induction by the Bad-mimetic ABT-737.

Taken together, our data show that the promising anti-neoplastic drug Celecoxib induces apoptosis in Jurkat T lymphoma cells through the Mcl-1/Noxa pathway by downregulation of Mcl-1 and activation of Bak. Our results suggest that similar to Jurkat cells, malignant cells whose survival depends on Mcl-1 expression may benefit from treatment with the Mcl-1 antagonist Celecoxib. Several groups already described an enhanced susceptibility of tumor cells to apoptosis induction in response to Mcl-1 downregulation [29, 49, 50]. Since Bcl-xL, like Mcl-1, is often overexpressed in tumor cells, a therapy that targets only Mcl-1 would be without any effect. Therefore, in conditions of increased expression of further anti-apoptotic Bcl-2 family members, combined treatment of Celecoxib with Bad-mimetics like ABT-737 may be an interesting option for the treatment of apoptosis resistant tumors.

\section{Acknowledgements}

The work was supported by grants from the Federal Ministry of Education and Research (Fö. 01KS9602), the Interdisciplinary Center of Clinical Research Tübingen (IZKF, 1597), the German Research Foundation (DFG; IRTG1302/1), the Deutsche Krebshilfe/ Mildred-ScheelStiftung (107388) as well as the fortüne-Program of the University of Tübingen (1806-1-0). Pharmacia Pfizer kindly provided Celecoxib for our study.

\section{Contributions of the authors}

JR contributed contributed most of the experimental work and participated in the design of the study, data analysis and drafting the manuscript. SJE contributed significantly to data acquisition. A-CM contributed initial work on the Mcl-1 antagonistic effects of Celecoxib. $\mathrm{CB}$ participated in the interpretation of the data. VJ performed conception and design of the study and substantially contributed to interpretation of data, critical revision of the manuscript and final approval. All authors read and approved the final manuscript. 


\section{References:}

[1] Belka C, Rudner J, Wesselborg S, Stepczynska A, Marini P, Lepple-Wienhues A, et al. Differential role of caspase- 8 and BID activation during radiation- and CD95induced apoptosis. Oncogene 2000;19:1181-90.

[2] Habermehl D, Kammerer B, Handrick R, Eldh T, Gruber C, Cordes N, et al. Proapoptotic activity of Ukrain is based on Chelidonium majus L. alkaloids and mediated via a mitochondrial death pathway. BMC Cancer 2006;6:14.

[3] Weinmann M, Jendrossek V, Handrick R, Guner D, Goecke B, Belka C. Molecular ordering of hypoxia-induced apoptosis: critical involvement of the mitochondrial death pathway in a FADD/caspase-8 independent manner. Oncogene 2004;23:375769.

[4] You H, Pellegrini M, Tsuchihara K, Yamamoto K, Hacker G, Erlacher M, et al. FOXO3a-dependent regulation of Puma in response to cytokine/growth factor withdrawal. J Exp Med 2006;203:1657-63.

[5] Adams JM, Cory S. The Bcl-2 apoptotic switch in cancer development and therapy. Oncogene 2007;26:1324-37.

[6] Certo M, Del Gaizo Moore V, Nishino M, Wei G, Korsmeyer S, Armstrong SA, et al. Mitochondria primed by death signals determine cellular addiction to antiapoptotic BCL-2 family members. Cancer Cell 2006;9:351-65.

[7] Youle RJ, Strasser A. The BCL-2 protein family: opposing activities that mediate cell death. Nat Rev Mol Cell Biol 2008;9:47-59.

[8] Ruffolo SC, Shore GC. BCL-2 selectively interacts with the BID-induced open conformer of BAK, inhibiting BAK auto-oligomerization. J Biol Chem 2003;278:25039-45.

[9] Bouillet P, Huang DC, O'Reilly LA, Puthalakath H, O'Connor L, Cory S, et al. The role of the pro-apoptotic Bcl-2 family member bim in physiological cell death. Ann N Y Acad Sci 2000;926:83-9.

[10] Galonek HL, Hardwick JM. Upgrading the BCL-2 network. Nat Cell Biol 2006;8:1317-9.

[11] Letai A, Bassik MC, Walensky LD, Sorcinelli MD, Weiler S, Korsmeyer SJ. Distinct BH3 domains either sensitize or activate mitochondrial apoptosis, serving as prototype cancer therapeutics. Cancer Cell 2002;2:183-92.

[12] Wei MC, Lindsten T, Mootha VK, Weiler S, Gross A, Ashiya M, et al. tBID, a membrane-targeted death ligand, oligomerizes BAK to release cytochrome c. Genes Dev 2000;14:2060-71.

[13] Chen L, Willis SN, Wei A, Smith BJ, Fletcher JI, Hinds MG, et al. Differential targeting of prosurvival Bcl-2 proteins by their $\mathrm{BH} 3$-only ligands allows complementary apoptotic function. Mol Cell 2005;17:393-403.

[14] Zha S, Yegnasubramanian V, Nelson WG, Isaacs WB, De Marzo AM. Cyclooxygenases in cancer: progress and perspective. Cancer Lett 2004;215:1-20.

[15] Uchida K. A lipid-derived endogenous inducer of COX-2: a bridge between inflammation and oxidative stress. Mol Cells 2008;25:347-51.

[16] Grosch S, Tegeder I, Niederberger E, Brautigam L, Geisslinger G. COX-2 independent induction of cell cycle arrest and apoptosis in colon cancer cells by the selective COX-2 inhibitor celecoxib. Faseb J 2001;15:2742-4.

[17] Muller AC, Handrick R, Elsaesser SJ, Rudner J, Henke G, Ganswindt U, et al. Importance of Bak for celecoxib-induced apoptosis. Biochem Pharmacol 2008;76:1082-96. 
[18] Song X, Lin HP, Johnson AJ, Tseng PH, Yang YT, Kulp SK, et al. Cyclooxygenase-2, player or spectator in cyclooxygenase-2 inhibitor-induced apoptosis in prostate cancer cells. J Natl Cancer Inst 2002;94:585-91.

[19] Waskewich C, Blumenthal RD, Li H, Stein R, Goldenberg DM, Burton J. Celecoxib exhibits the greatest potency amongst cyclooxygenase (COX) inhibitors for growth inhibition of COX-2-negative hematopoietic and epithelial cell lines. Cancer Res 2002;62:2029-33.

[20] Ding H, Han C, Zhu J, Chen CS, D'Ambrosio SM. Celecoxib derivatives induce apoptosis via the disruption of mitochondrial membrane potential and activation of caspase 9. Int J Cancer 2005;113:803-10.

[21] Hsu AL, Ching TT, Wang DS, Song X, Rangnekar VM, Chen CS. The cyclooxygenase-2 inhibitor celecoxib induces apoptosis by blocking Akt activation in human prostate cancer cells independently of Bcl-2. J Biol Chem 2000;275:11397403.

[22] Jendrossek V, Handrick R, Belka C. Celecoxib activates a novel mitochondrial apoptosis signaling pathway. Faseb J 2003;17:1547-9.

[23] Johnson AJ, Smith LL, Zhu J, Heerema NA, Jefferson S, Mone A, et al. A novel celecoxib derivative, OSU03012, induces cytotoxicity in primary CLL cells and transformed B-cell lymphoma cell line via a caspase- and Bcl-2-independent mechanism. Blood 2005;105:2504-9.

[24] Rudner J, Lepple-Wienhues A, Budach W, Berschauer J, Friedrich B, Wesselborg S, et al. Wild-type, mitochondrial and ER-restricted Bcl-2 inhibit DNA damage-induced apoptosis but do not affect death receptor-induced apoptosis. J Cell Sci 2001;114:4161-72.

[25] Han J, Goldstein LA, Gastman BR, Rabinowich H. Interrelated roles for Mcl-1 and $\mathrm{BIM}$ in regulation of TRAIL-mediated mitochondrial apoptosis. J Biol Chem 2006;281:10153-63.

[26] Dai H, Meng XW, Lee SH, Schneider PA, Kaufmann SH. Context-dependent Bcl2/Bak interactions regulate lymphoid cell apoptosis. J Biol Chem 2009.

[27] Sinha-Datta U, Taylor JM, Brown M, Nicot C. Celecoxib disrupts the canonical apoptotic network in HTLV-I cells through activation of Bax and inhibition of PKB/Akt. Apoptosis 2008;13:33-40.

[28] Alves NL, Derks IA, Berk E, Spijker R, van Lier RA, Eldering E. The Noxa/Mcl-1 axis regulates susceptibility to apoptosis under glucose limitation in dividing $\mathrm{T}$ cells. Immunity 2006;24:703-16.

[29] Gomez-Bougie P, Wuilleme-Toumi S, Menoret E, Trichet V, Robillard N, Philippe M, et al. Noxa up-regulation and Mcl-1 cleavage are associated to apoptosis induction by bortezomib in multiple myeloma. Cancer Res 2007;67:5418-24.

[30] Hallaert DY, Spijker R, Jak M, Derks IA, Alves NL, Wensveen FM, et al. Crosstalk among Bcl-2 family members in B-CLL: seliciclib acts via the Mcl-1/Noxa axis and gradual exhaustion of Bcl-2 protection. Cell Death Differ 2007;14:1958-67.

[31] Inoue S, Walewska R, Dyer MJ, Cohen GM. Downregulation of Mcl-1 potentiates HDACi-mediated apoptosis in leukemic cells. Leukemia 2008;22:819-25.

[32] Mei Y, Xie C, Xie W, Tian X, Li M, Wu M. Noxa/Mcl-1 balance regulates susceptibility of cells to camptothecin-induced apoptosis. Neoplasia 2007;9:871-81.

[33] Morales AA, Gutman D, Lee KP, Boise LH. BH3-only proteins Noxa, Bmf, and Bim are necessary for arsenic trioxide-induced cell death in myeloma. Blood 2008;111:5152-62.

[34] Czabotar PE, Lee EF, van Delft MF, Day CL, Smith BJ, Huang DC, et al. Structural insights into the degradation of Mcl-1 induced by BH3 domains. Proc Natl Acad Sci U S A 2007;104:6217-22. 
[35] Warr MR, Acoca S, Liu Z, Germain M, Watson M, Blanchette M, et al. BH3-ligand regulates access of MCL-1 to its E3 ligase. FEBS Lett 2005;579:5603-8.

[36] Panka DJ, Cho DC, Atkins MB, Mier JW. GSK-3beta inhibition enhances sorafenibinduced apoptosis in melanoma cell lines. J Biol Chem 2008;283:726-32.

[37] Willis SN, Chen L, Dewson G, Wei A, Naik E, Fletcher JI, et al. Proapoptotic Bak is sequestered by Mcl-1 and Bcl-xL, but not Bcl-2, until displaced by BH3-only proteins. Genes Dev 2005;19:1294-305.

[38] Sattler M, Liang H, Nettesheim D, Meadows RP, Harlan JE, Eberstadt M, et al. Structure of Bcl-xL-Bak peptide complex: recognition between regulators of apoptosis. Science 1997;275:983-6.

[39] Willis SN, Fletcher JI, Kaufmann T, van Delft MF, Chen L, Czabotar PE, et al. Apoptosis initiated when BH3 ligands engage multiple Bcl-2 homologs, not Bax or Bak. Science 2007;315:856-9.

[40] Zhai D, Jin C, Huang Z, Satterthwait AC, Reed JC. Differential regulation of Bax and Bak by anti-apoptotic Bcl-2 family proteins Bcl-B and Mcl-1. J Biol Chem 2008;283:9580-6.

[41] Kim H, Rafiuddin-Shah M, Tu HC, Jeffers JR, Zambetti GP, Hsieh JJ, et al. Hierarchical regulation of mitochondrion-dependent apoptosis by BCL-2 subfamilies. Nat Cell Biol 2006;8:1348-58.

[42] Konopleva M, Watt J, Contractor R, Tsao T, Harris D, Estrov Z, et al. Mechanisms of antileukemic activity of the novel Bcl-2 homology domain-3 mimetic GX15-070 (obatoclax). Cancer Res 2008;68:3413-20.

[43] Huang S, Sinicrope FA. BH3 mimetic ABT-737 potentiates TRAIL-mediated apoptotic signaling by unsequestering Bim and Bak in human pancreatic cancer cells. Cancer Res 2008;68:2944-51.

[44] Kang MH, Wan Z, Kang YH, Sposto R, Reynolds CP. Mechanism of synergy of N-(4hydroxyphenyl)retinamide and ABT-737 in acute lymphoblastic leukemia cell lines: Mcl-1 inactivation. J Natl Cancer Inst 2008;100:580-95.

[45] Kuroda J, Kimura S, Andreeff M, Ashihara E, Kamitsuji Y, Yokota A, et al. ABT-737 is a useful component of combinatory chemotherapies for chronic myeloid leukaemias with diverse drug-resistance mechanisms. Br J Haematol 2008;140:181-90.

[46] Paoluzzi L, Gonen M, Bhagat G, Furman RR, Gardner JR, Scotto L, et al. The BH3only mimetic ABT-737 synergizes the anti-neoplastic activity of proteasome inhibitors in lymphoid malignancies. Blood 2008.

[47] Witham J, Valenti MR, De-Haven-Brandon AK, Vidot S, Eccles SA, Kaye SB, et al. The Bcl-2/Bcl-XL family inhibitor ABT-737 sensitizes ovarian cancer cells to carboplatin. Clin Cancer Res 2007;13:7191-8.

[48] Zhang W, Konopleva M, Ruvolo VR, McQueen T, Evans RL, Bornmann WG, et al. Sorafenib induces apoptosis of AML cells via Bim-mediated activation of the intrinsic apoptotic pathway. Leukemia 2008;22:808-18.

[49] Wei SH, Dong K, Lin F, Wang X, Li B, Shen JJ, et al. Inducing apoptosis and enhancing chemosensitivity to Gemcitabine via RNA interference targeting Mcl-1 gene in pancreatic carcinoma cell. Cancer Chemother Pharmacol 2008.

[50] Wolter KG, Verhaegen M, Fernandez Y, Nikolovska-Coleska Z, Riblett M, de la Vega $\mathrm{CM}$, et al. Therapeutic window for melanoma treatment provided by selective effects of the proteasome on Bcl-2 proteins. Cell Death Differ 2007;14:1605-16. 


\section{Legends:}

Figure 1: Celecoxib-induced apoptosis involves Bak-activation upstream of caspase activation. (A) Jurkat E6.1 cells were treated with 50, 75, or $100 \mu \mathrm{M}$ Celecoxib. At indicated time points DNA fragmentation, as indicated by the analysis of the sub G1 peak, and breakdown of the mitochondrial membrane potential $(\Delta \Psi \mathrm{m})$ were analyzed by flow cytometry. Data show mean values $+/-$ s.d. of 3 independent experiments. (B) Activation of caspase-9, caspase-3, and cleavage of the caspase-3 substrate PARP in response to Celecoxib was detected by Western blotting. Caspases were fully activated already $3 \mathrm{~h}$ after treatment with Celecoxib in a concentration-dependent manner. (C) No COX-2 expression could be detected in Jurkat E6.1 cells suggesting a COX-2-independent mechanism of Celecoxibinduced apoptosis. The human lung carcinoma cell line A549 which express COX-2 was used as a positive control. Two bands could be detected, the upper one is probably a highly glycosylated form of COX-2. $\alpha / \beta$-Tubulin was used as loading control. (D, E) $6 \mathrm{~h}$ after treatment with Celecoxib cells were fixed, permeabilized, and stained with an antibody that recognizes the active conformation of Bak and analyzed by flow cytometry. (D) Treatment with $75 \mu \mathrm{M}$ or $100 \mu \mathrm{M}$ Celecoxib resulted in Bak activation as indicated by a specific increase in fluorescence intensity. Co-treatment with $30 \mu \mathrm{M}$ pan-caspase inhibitor zVAD-fmk did not abrogate Bak activation (E) or $\Delta \Psi_{\mathrm{m}}$ breakdown in response to $75 \mu \mathrm{M}$ Celecoxib (F), indicating that activation of Bak and $\Delta \Psi_{\mathrm{m}}$ breakdown occurred upstream of caspase activation. Results show one representative experiment out of 3 .

\section{Figure 2: Downregulation of Mcl-1 is an essential step during Celecoxib-induced} apoptosis. (A) Jurkat E6.1 cells were treated with 50, 75, or $100 \mu \mathrm{M}$ Celecoxib. After 6h, cells were lysed and subsequently analyzed by Western blotting with the indicated antibodies. Mcl-1 was clearly downregulated at $50 \mu \mathrm{M}$ Celecoxib and not detectable when treated with higher concentrations of Celecoxib whereas Noxa, Bak, Bcl-2, and Bcl-xL levels remained unchanged. (B-D) Jurkat cells were electroporated with different amounts of mcl-1 siRNA. As control, the unspecific non-targeting siRNA (nt) was transfected into the cells. $6 \mathrm{~h}$ after electroporation, cells were analyzed by Western blotting (B) and flow cytometry measuring DNA fragmentation (C) and $\Delta \Psi_{\mathrm{m}}$ breakdown (D). Silencing of Mcl-1 was sufficient to induce apoptosis. Results show mean values $+/-$ s.d. of 3 independent experiments. 


\section{Figure 3: Celecoxib induces apoptosis through the Mcl-1/Noxa axis.}

(A) Jurkat E6.1 cells were treated for $6 \mathrm{~h}$ with $75 \mu \mathrm{M}$ Celecoxib or left untreated. Immunoprecipitation studies using specific antibodies against Mcl-1 or Noxa revealed that Noxa interacts with Mcl-1 in healthy cells. This interaction was diminished when Mcl-1 was downregulated by Celecoxib-treatment. For comparison the expression levels of Mcl-1 and Noxa were shown in untreated whole cell lysates (WCL, $60 \mu \mathrm{g}$ ). (B-E) To examine the involvement of Noxa in Celecoxib-induced apoptosis, Jurkat E6.1 cells were silenced with $500 \mathrm{nM}$ noxa siRNA for $24 \mathrm{~h}$ before treatment with $75 \mu \mathrm{M}$ Celecoxib (D) or Mcl-1 downregulation by siRNA (E) . As control, non-targeting siRNA (nt) was transfected at the same concentration. (B) The downregulation of Noxa was verified by Western blotting $24 \mathrm{~h}$ after electroporation. (C-E) Apoptosis was determined by DNA fragmentation (sub G1) using flow cytometry. (C) Silencing of the pro-apoptotic Noxa did change background apoptosis. In contrast, electroporation of $500 \mathrm{nM}$ mcl-1 siRNA was sufficient to induce DNA fragmentation. (D) Silencing of the pro-apoptotic Noxa rendered the cells refractory to Celecoxib-induced apoptosis. (E) Downregulation of Mcl-1 by $250 \mathrm{nM}$ siRNA induced apoptosis regardless of Noxa expression indicating that Noxa acts upstream of Mcl-1.

Flow cytometric results represent means +/- s.d. of 3 independent experiments.

Figure 4: Bcl-xL but not Bcl-2 interferes with apoptosis induction in response to

Celecoxib. Jurkat E6.1 cells were stably transfected with a vector containing the Bcl-2 or Bcl$\mathrm{xL}$ sequence or with the empty control vector, respectively. (A) Overexpression of Bcl-2 and Bcl-xL and similar expression of Mcl-1 and Bak was verified by Western blotting. (B) 12h after treatment with Celecoxib at the indicated concentrations, double staining of Hoechst 33342 and propidium iodide was performed to distinguish between healthy (blue, diffuse DNA staining), early apoptotic (blue, condensed DNA staining), late apoptotic (red, condensed DNA staining), and necrotic cells (red, diffuse DNA staining). (B) Fluorescence microscopic analysis showed apoptosis induction in Jurkat Vector and Jurkat Bcl-2 cells, whereas necrotic cell death was negligible. Overexpression of $\mathrm{Bcl}-\mathrm{xL}$ protected from both forms of cell death. Cells were counted by 3 different people and summarized in the graph showing the mean values $+/-$ s.d. of the 3 independent counts. (C-F) Jurkat Vector, Bcl-2, and Bcl-xL cells were treated with Celecoxib at indicated concentrations for $6 \mathrm{~h}$ and subsequently subjected to flow cytometric evaluation of $\Delta \Psi_{\mathrm{m}}$ breakdown (C), Western blot analysis of caspase-activation (D), flow cytometric evaluation of Bak-activation (E) and cytochrome C release from the mitochondria into the cytosol $(\mathrm{F})$. Overexpression of Bcl-xL inhibited 
Celecoxib-induced Bak activation (E), $\Delta \Psi_{\mathrm{m}}$ breakdown (C), caspase activation (D), and cytochrome $\mathrm{C}$ release (F), whereas Bcl-2 showed hardly any effect. However, overexpression of Bcl-xL could not impede the downregulation of Mcl-1 (D). (C) shows mean values +/- s.d. of 3 independent experiments, (D-F) one representative experiment out of 3.

\section{Figure 5: Silencing of Mcl-1 was not sufficient to induce apoptosis in Bcl-2 and Bcl-xL} overexpressing cells. Jurkat cells overexpressing Bcl-2 or Bcl-xL and the Vector counterparts were transfected with $500 \mathrm{nM}$ mcl-1 siRNA (mcl-1) or non-targeting siRNA (nt) respectively. $6 \mathrm{~h}$ after electroporation, DNA fragmentation (A, upper panel) and $\Delta \Psi_{\mathrm{m}}$ breakdown (A, lower panel) were examined by flow cytometry, caspase activation and silencing of Mcl-1 by Western blotting (B). Downregulation of Mcl-1 slightly increased sub G1 and low $\Delta \Psi_{\mathrm{m}}$ levels above the background and also induced a weak caspase activation in Bcl-2 and Bcl-xL overexpressing cells, but was insufficient to effectively induce apoptosis as observed in Jurkat Vector controls. (C) $24 \mathrm{~h}$ after electroporation with $500 \mathrm{nM}$ mcl-1 siRNA (mcl-1) or nontargeting siRNA (nt), the cells were treated with $75 \mu \mathrm{M}$ Celecoxib for $6 \mathrm{~h}$ and subsequently analyzed for DNA fragmentation $\left(\mathrm{C}\right.$, upper panel) and $\Delta \Psi_{\mathrm{m}}$ breakdown $(\mathrm{C}$, lower panel). The data show that Bcl-xL overexpressing cells with impaired Mcl-1 expression remained refractory to Celecoxib-induced apoptosis, whereas DNA degradation and $\Delta \Psi_{\mathrm{m}}$ breakdown readily occurred in Jurkat Bcl-2 cells or Vector control transfected with non-targeting siRNA (nt). Data of flow cytometric analysis represent mean values $+/-$ s.d. of 3 independent experiments, western blot analysis shows one representative experiment out of 3 .

Figure 6: Neutralization of both, Mcl-1 and Bcl-xL is necessary for a successful induction of apoptosis in Bcl-xL overexpressing cells. (A) Transfection of Bcl-xL overexpressing Jurkat cells with $500 \mathrm{nM}$ mcl-1 or bcl-x siRNA alone did not induce apoptosis. Silencing of Bcl-xL in Jurkat Vector cells elevated apoptotic levels but did not induce DNA degradation as efficiently as mcl-1 siRNA. However, when Bcl-xL expression was inhibited, apoptosis sensitivity of Jurkat Bcl-xL cells in response to Celecoxib (C) and Mcl-1 silencing (E) was restored. For the flow cytometric analysis cells were electroporated with $500 \mathrm{nM}$ bcl-x siRNA $48 \mathrm{~h}$ before a $6 \mathrm{~h}$ treatment with Celecoxib (C) or a second electroporation with $500 \mathrm{nM}$ mcl-1 siRNA (E). The quantification of DNA fragmentation and $\Delta \Psi \mathrm{m}$ breakdown were preformed $12 \mathrm{~h}$ (sub G1) or $6 \mathrm{~h}(\Delta \Psi \mathrm{m}$ low) after treatment with Celecoxib (C) or the second electroporation (E), accordingly. Non-targeting siRNA (nt) was used at respective concentration. Mcl-1 and Bcl-xL expression levels in Jurkat Bcl-xL cells 
were examined by Western blotting. (B), (D), and (F) are the control experiments to those performed in (A), (C), and (E), respectively. (B) shows downregulation of Bcl-xL 24h, 48h, and 72h after electroporation with bcl-x siRNA, (D) shows Bcl-xL and Mcl-1 protein levels $48 \mathrm{~h}$ after transfection before the cells were treated with Celecoxib, and (F) shows Bcl-xL and Mcl-1 expression $6 \mathrm{~h}$ after the second electroporation with mcl-1 siRNA. Flow cytometric analysis (E) and lysats (F) were made at the same time. Data of flow cytometric analysis show mean values $+/$ - s.d. of 3 independent experiments. 
Fig 1
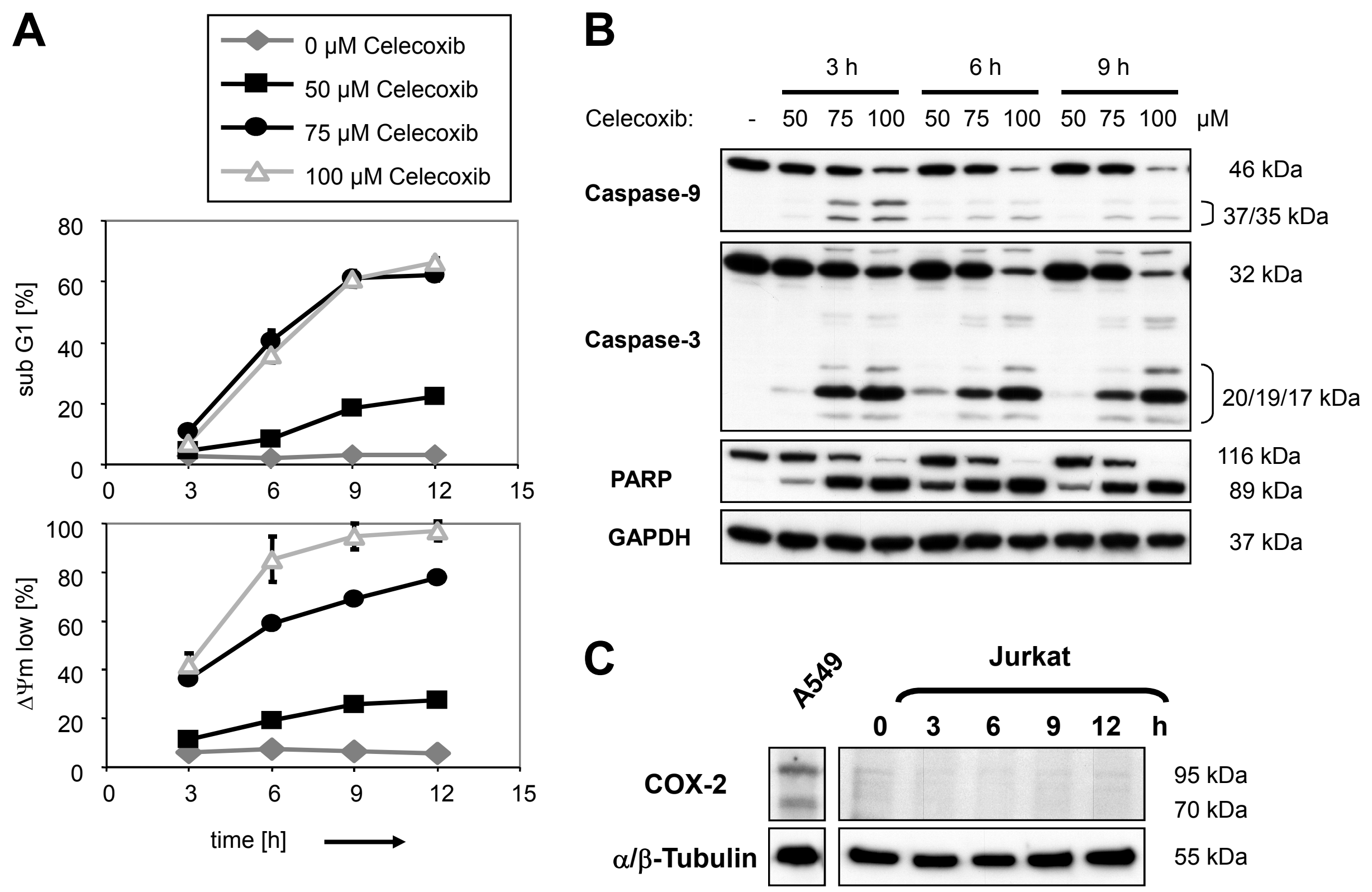
Fig 1

D

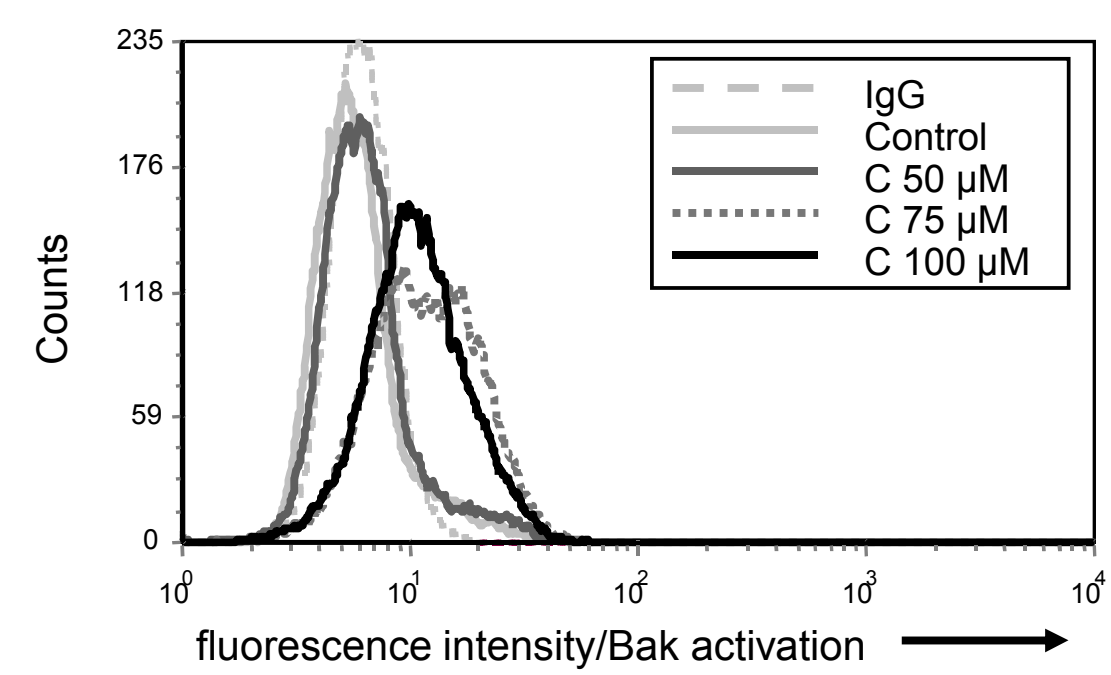

E

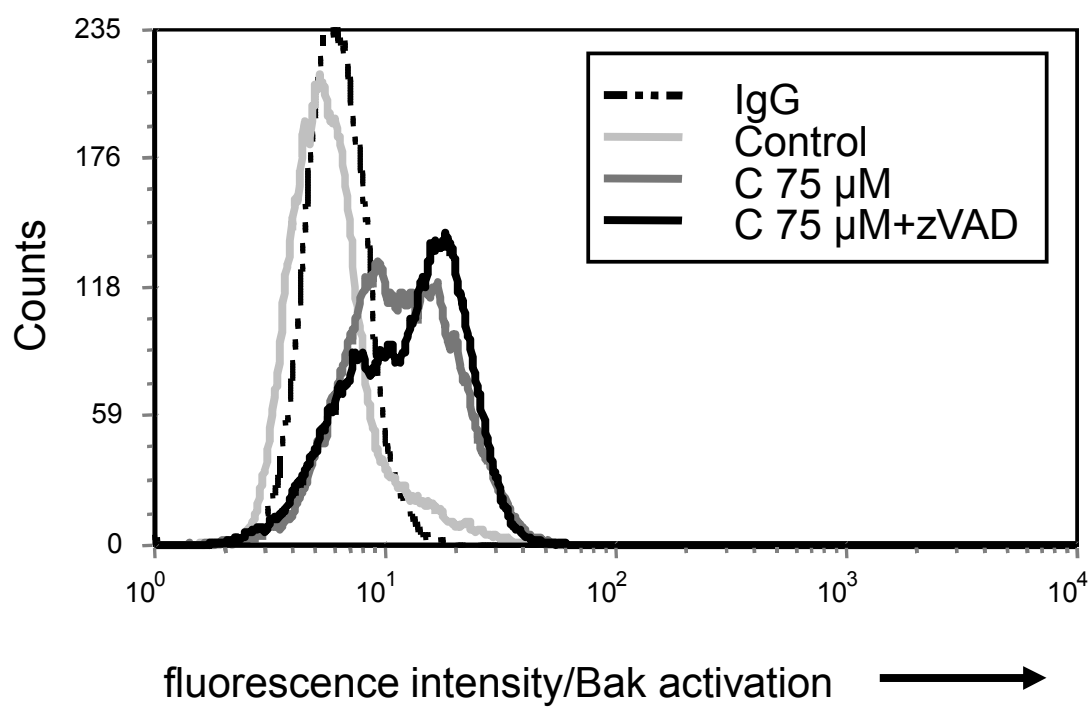

F
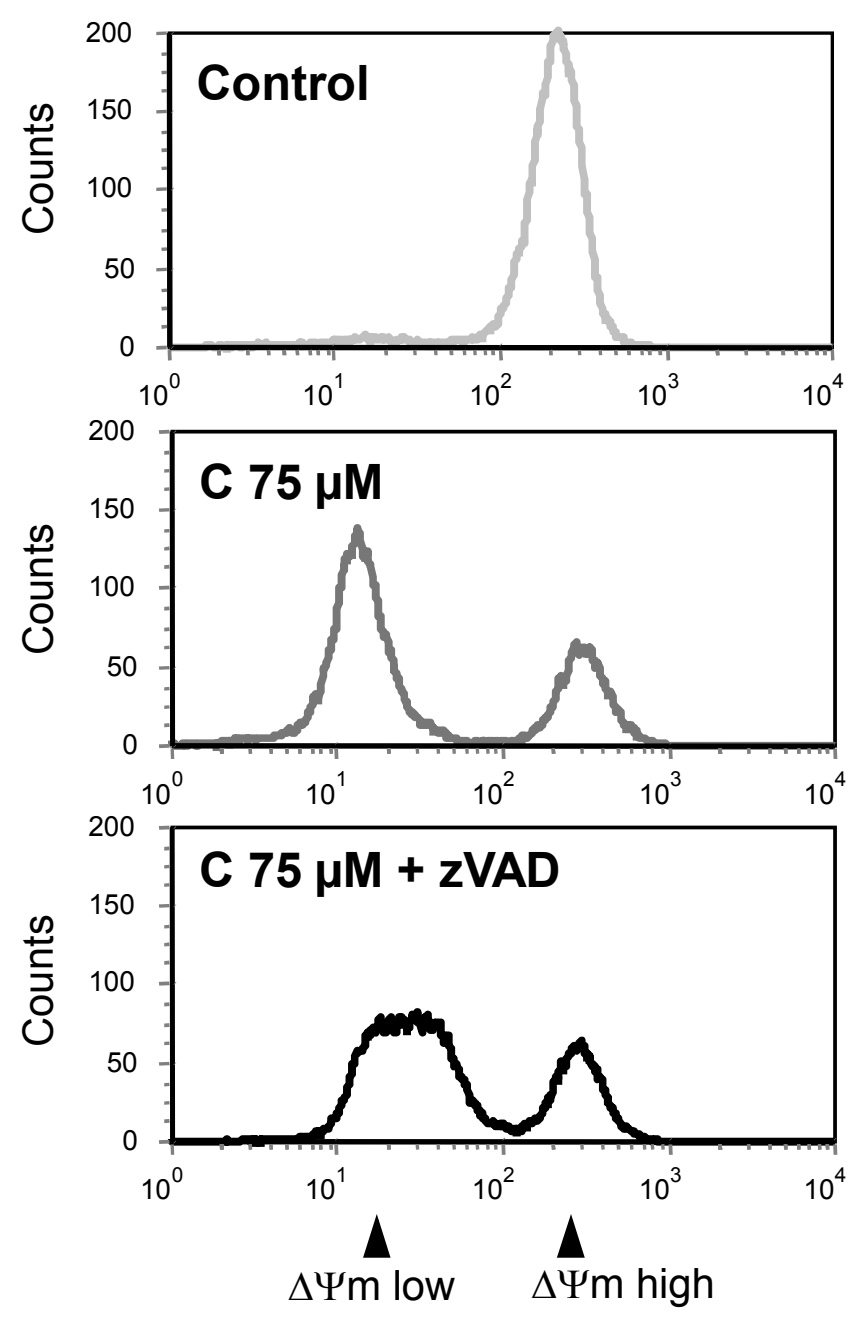
Fig 2

A

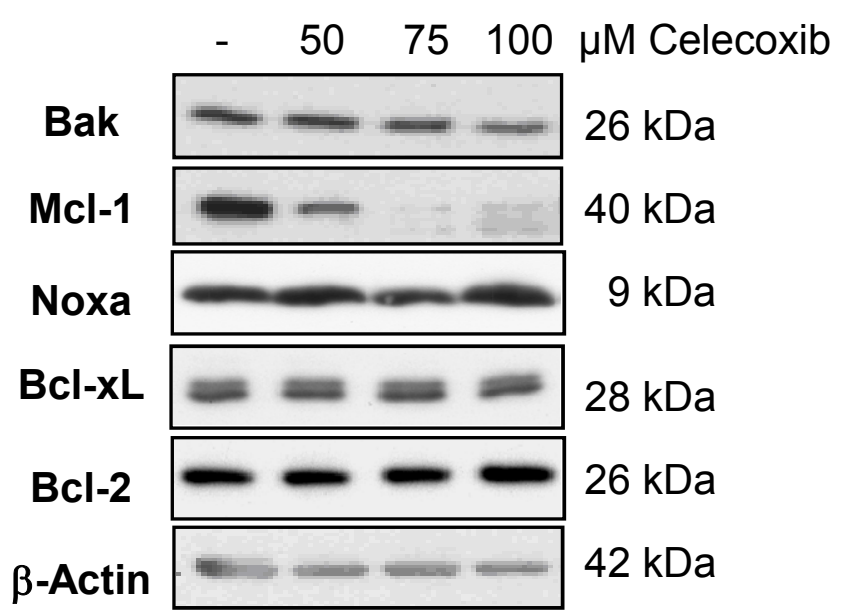

B

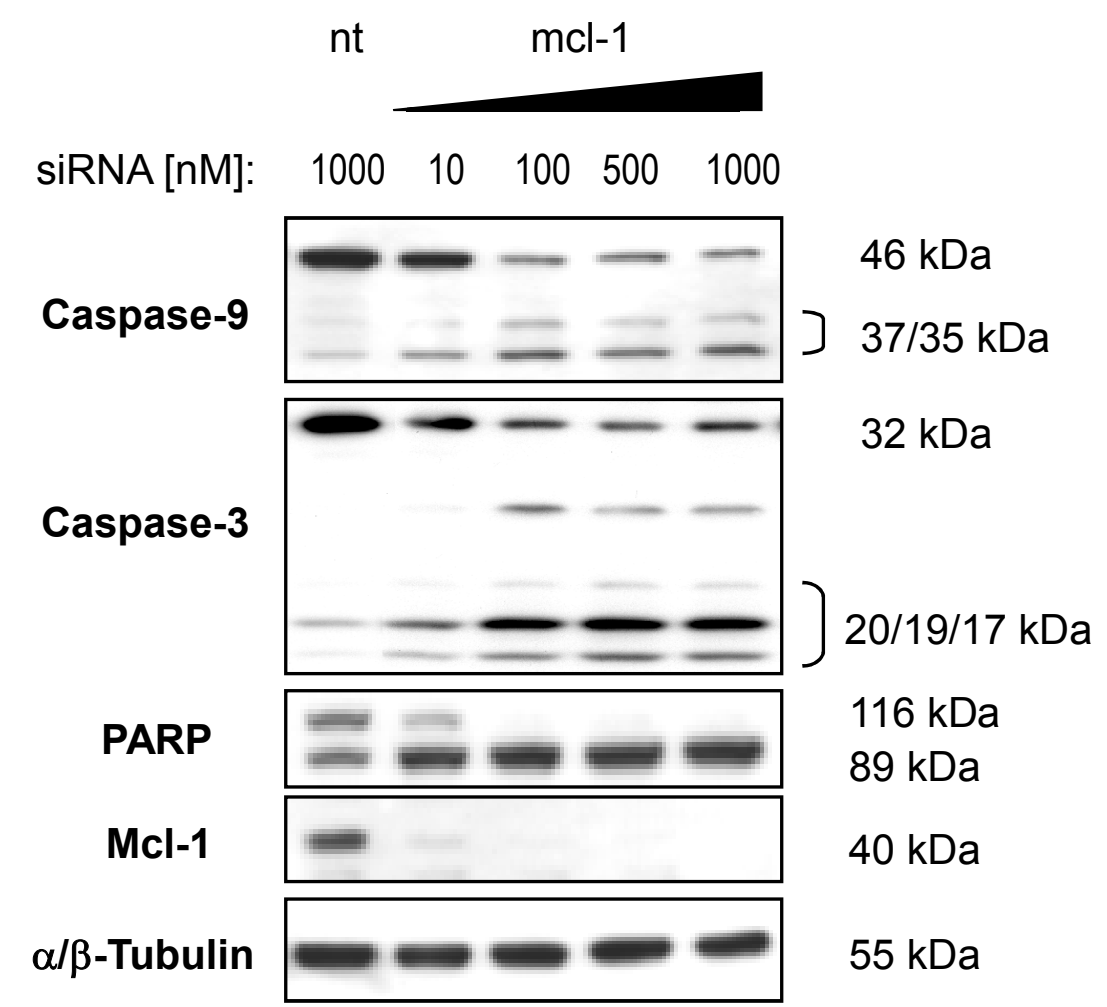

C

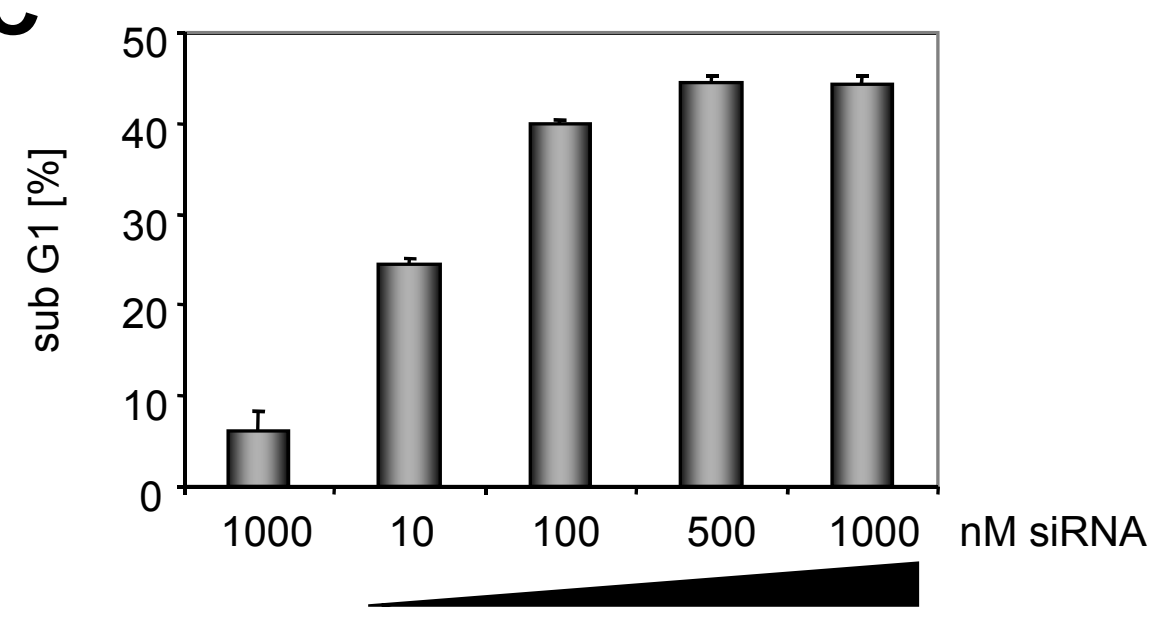

nt

mcl-1

D

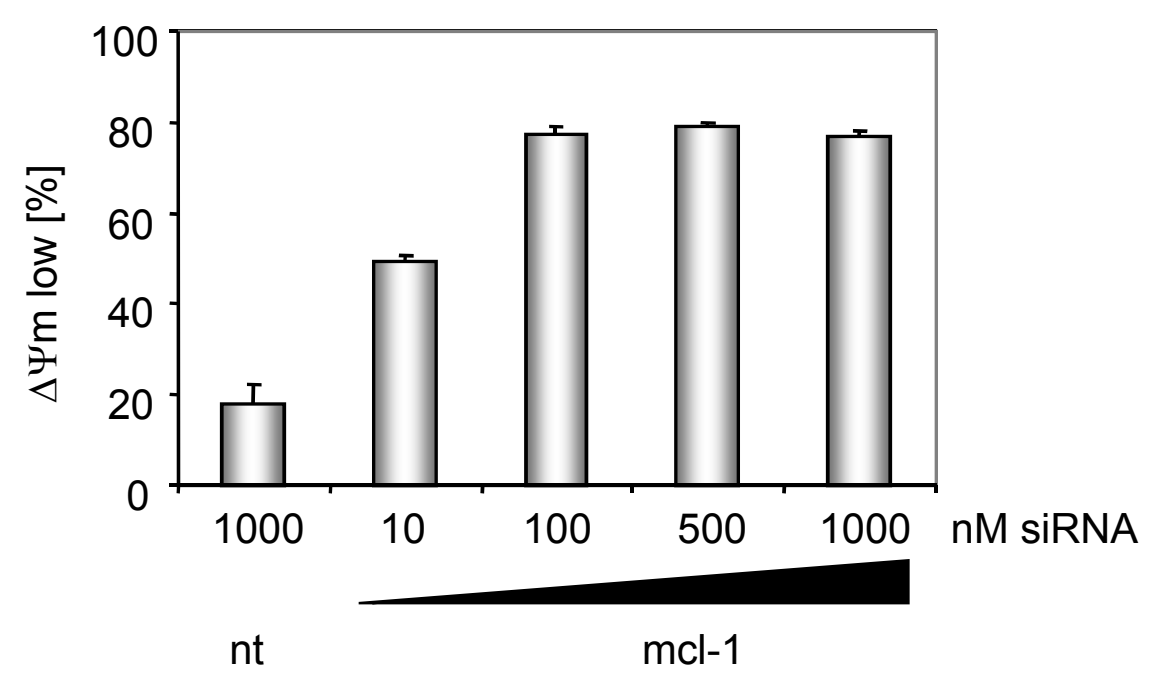


Fig 3

A

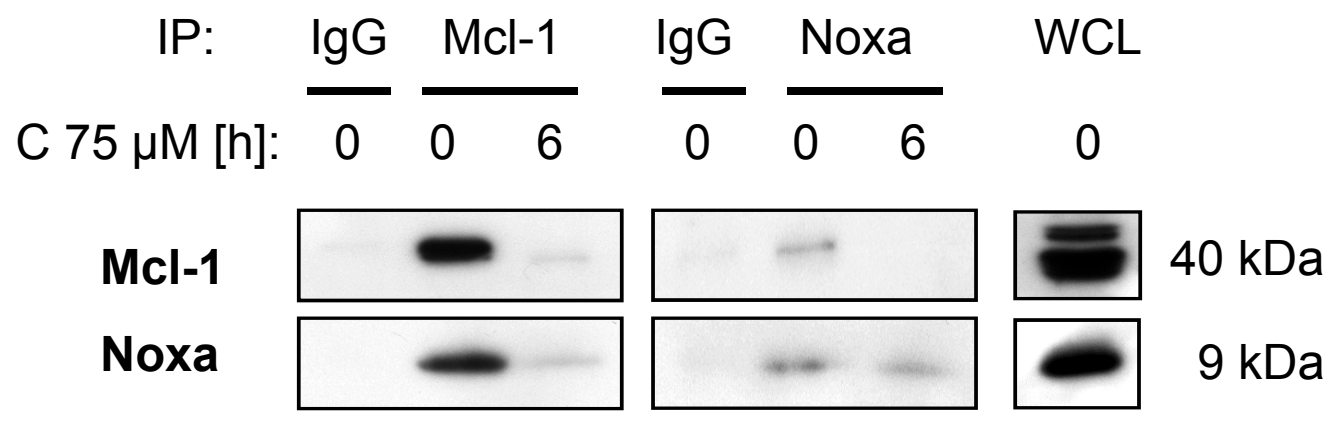

C

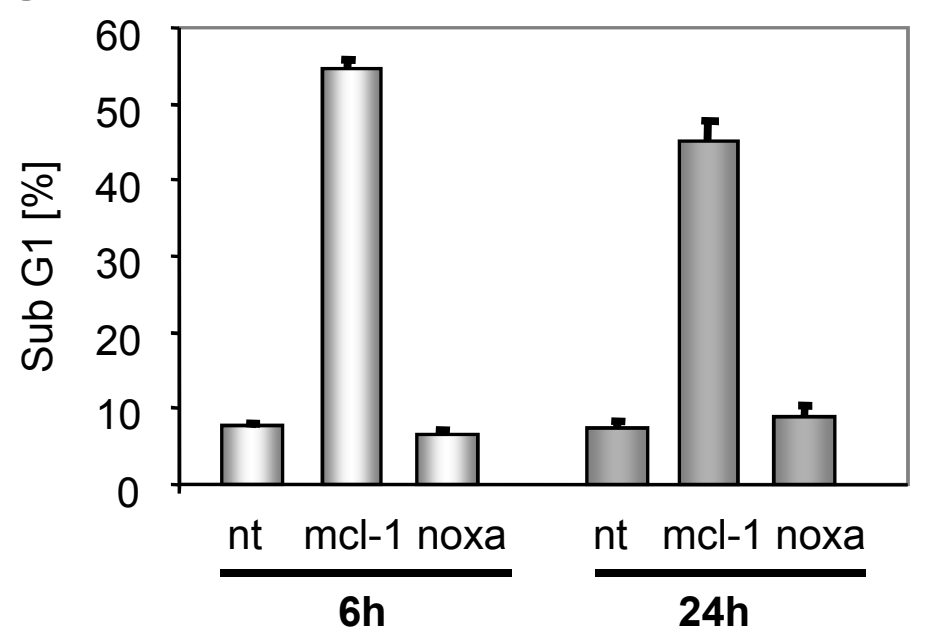

E

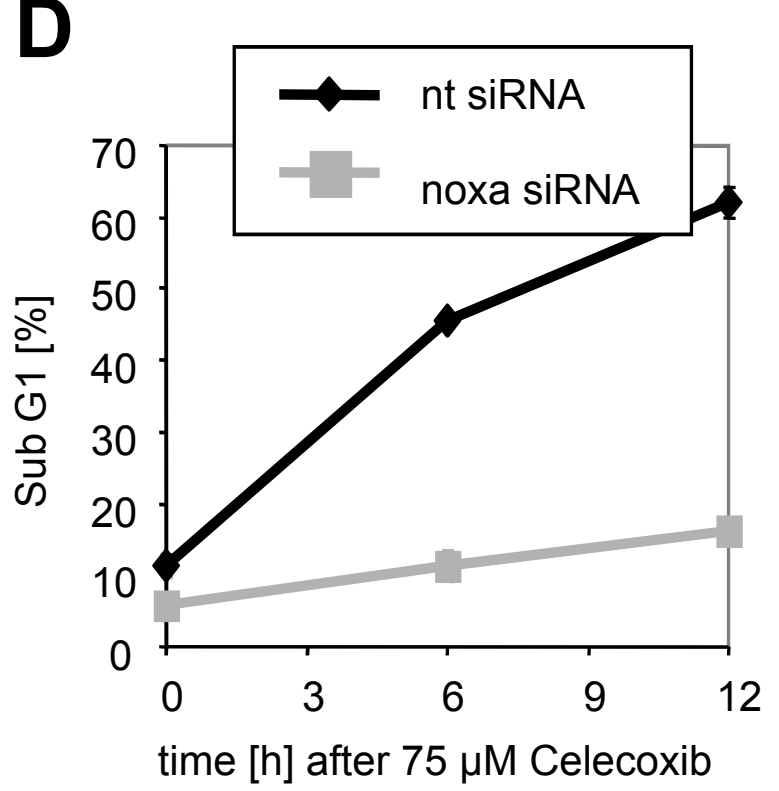

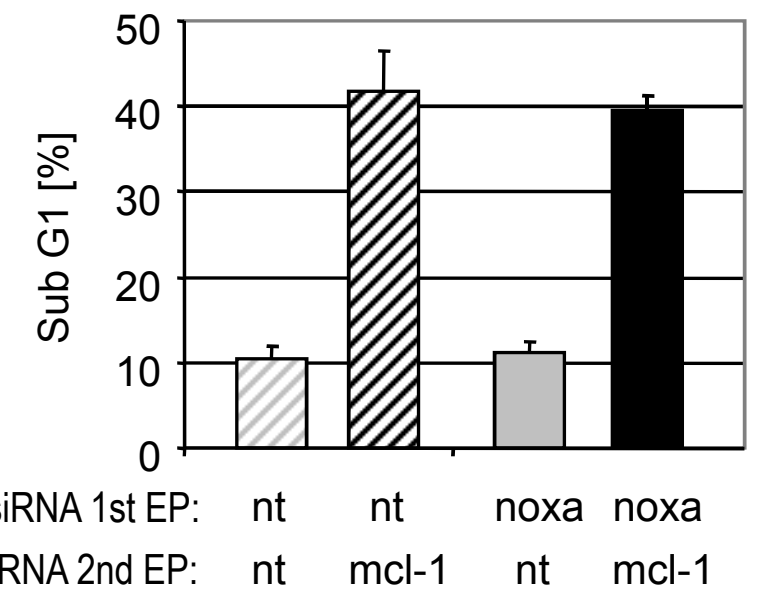


Fig 4

A
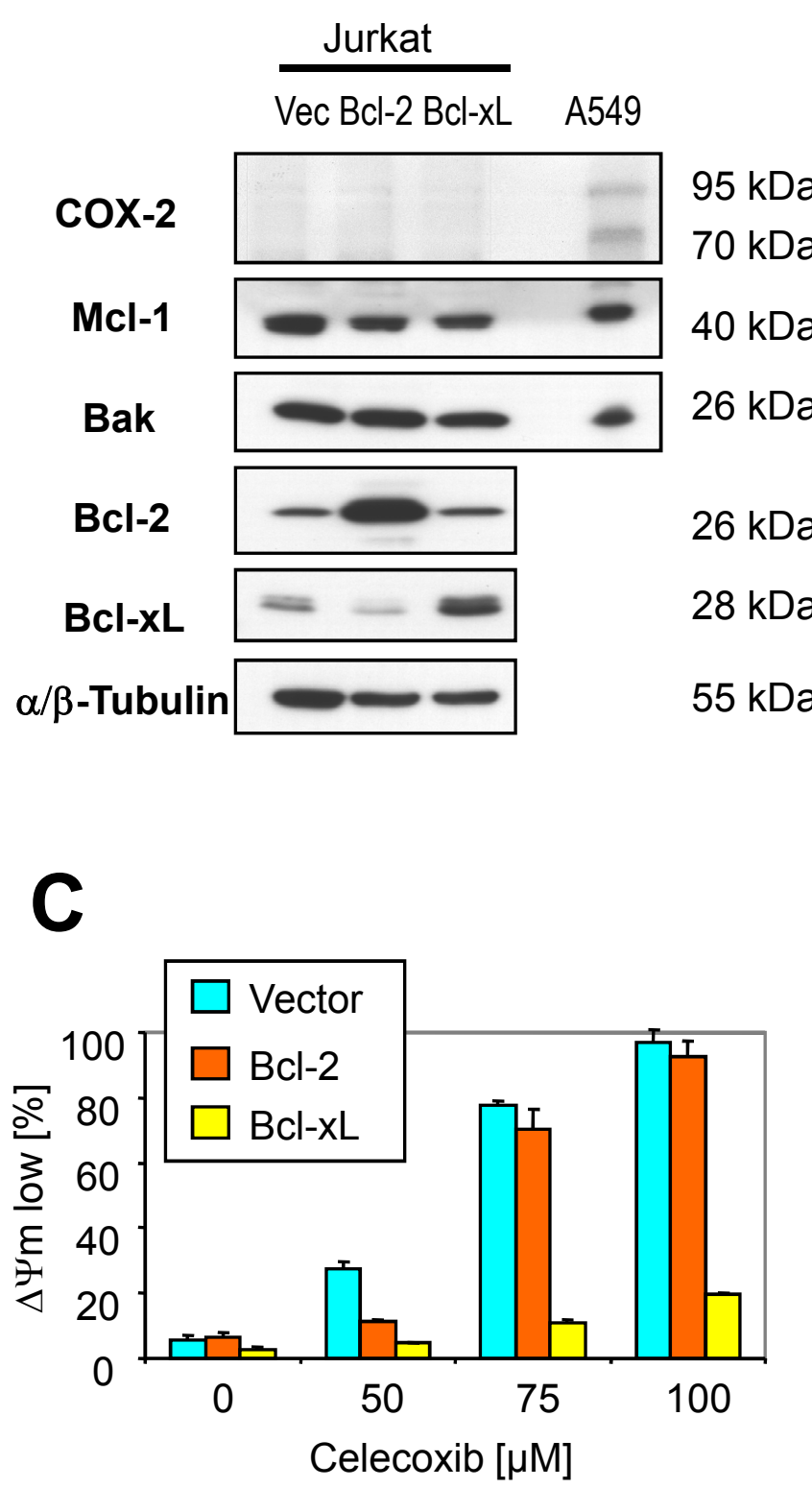

B
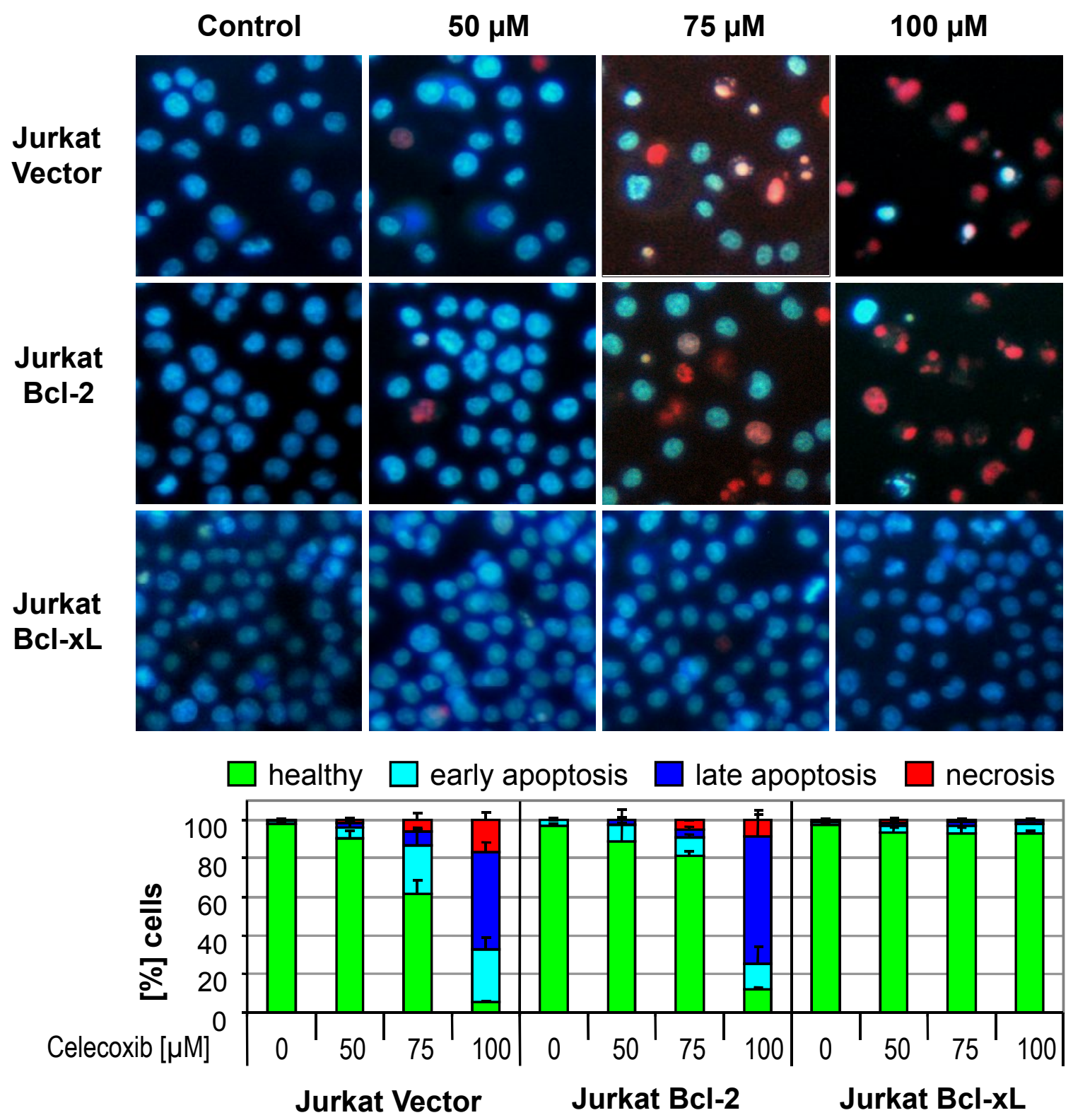
Fig 4

D

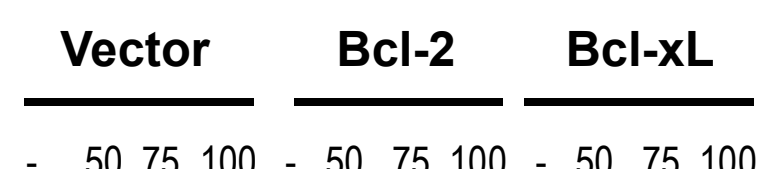

Celecoxib $[\mu \mathrm{M}]:-5075100$ - 5075100 - 5075100

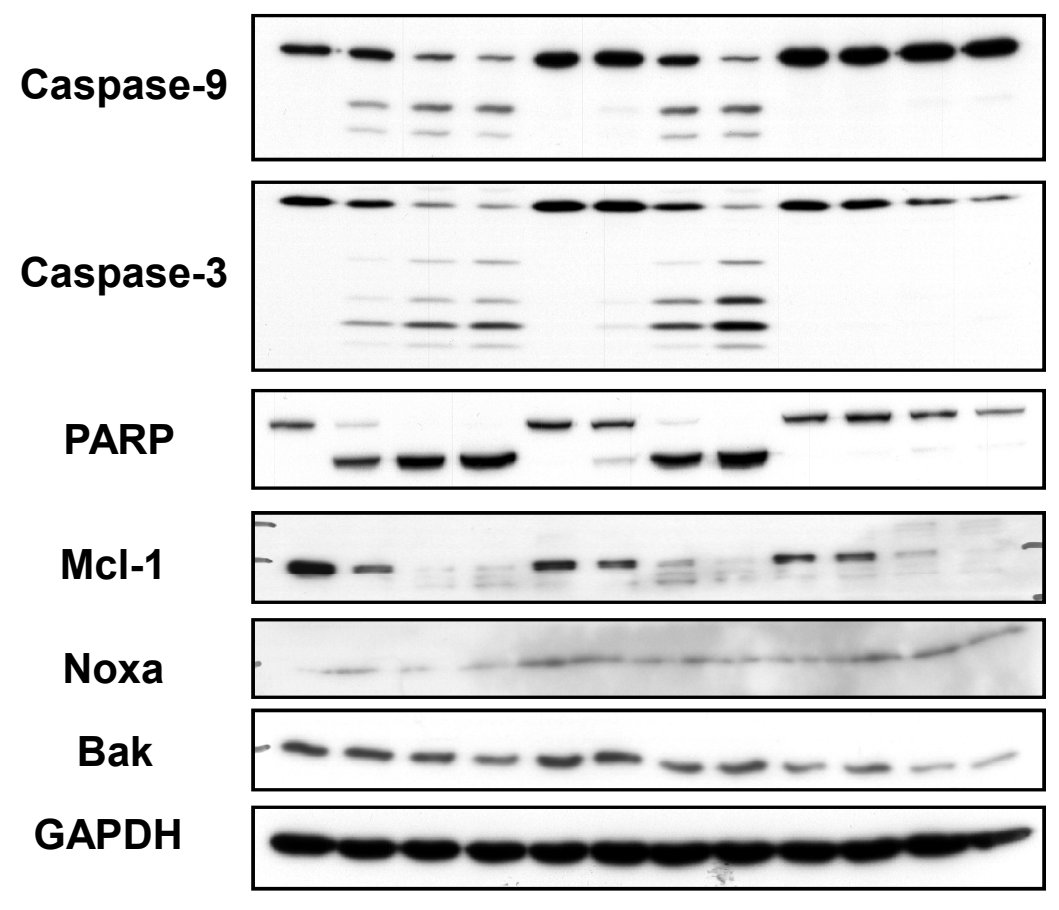

$46 \mathrm{kDa}$ ] $37 / 35 \mathrm{kDa}$

32 kDa 20/19/17 kDa

$116 \mathrm{kDa}$ 89 kDa $40 \mathrm{kDa}$ $9 \mathrm{kDa}$ $26 \mathrm{kDa}$ $37 \mathrm{kDa}$

F

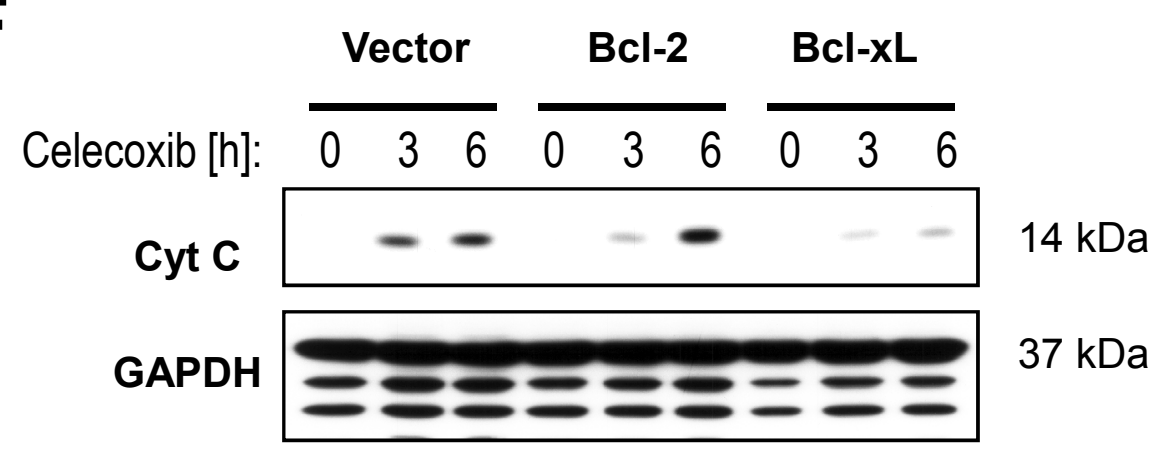

E
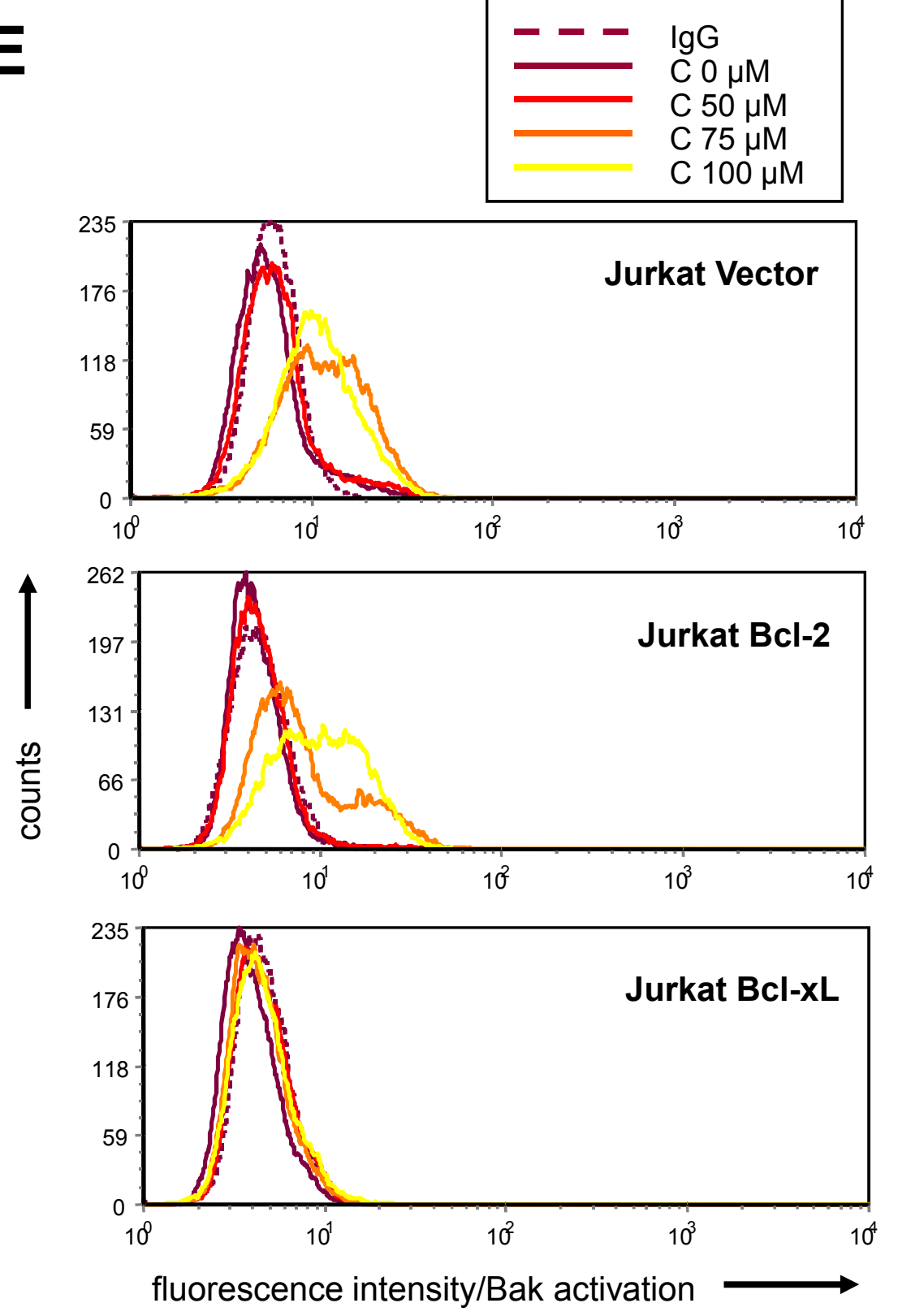
Fig 5

A
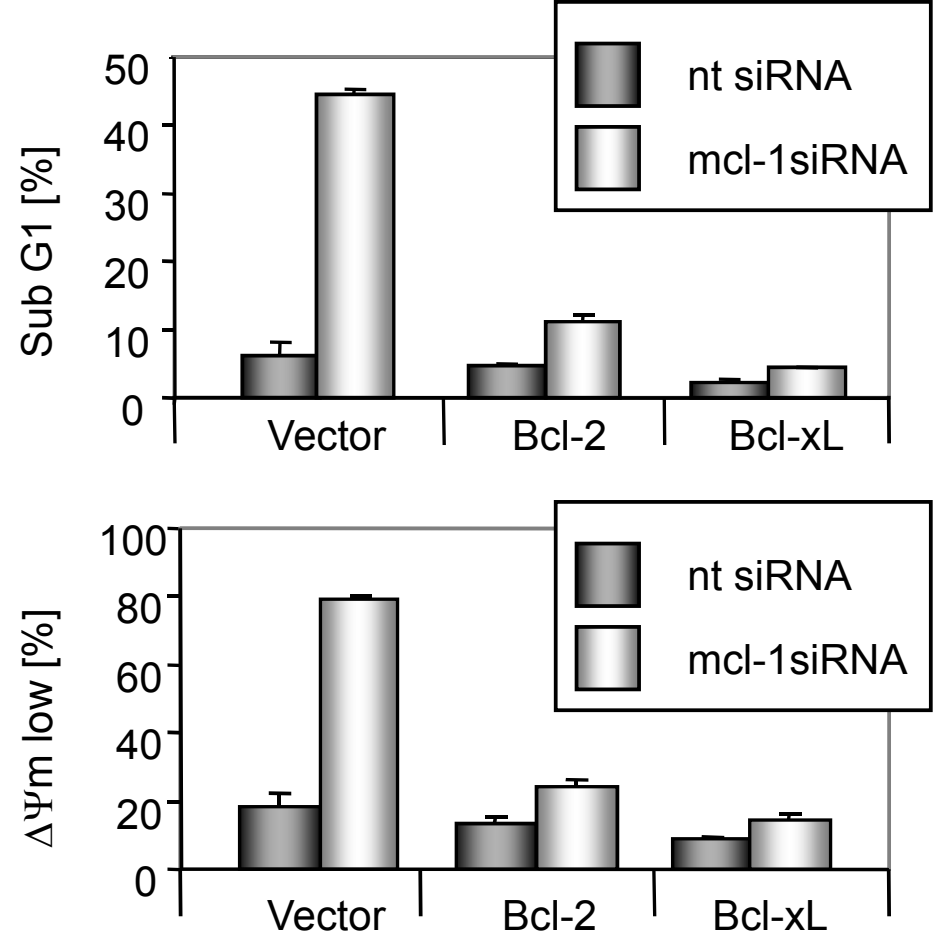

B

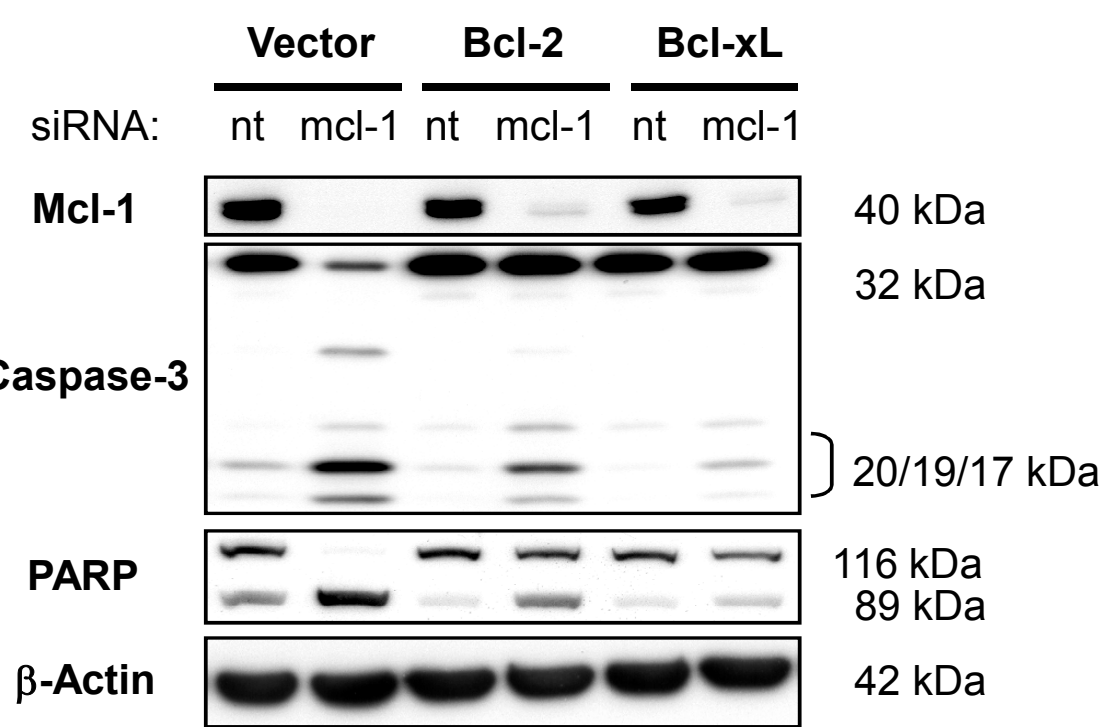

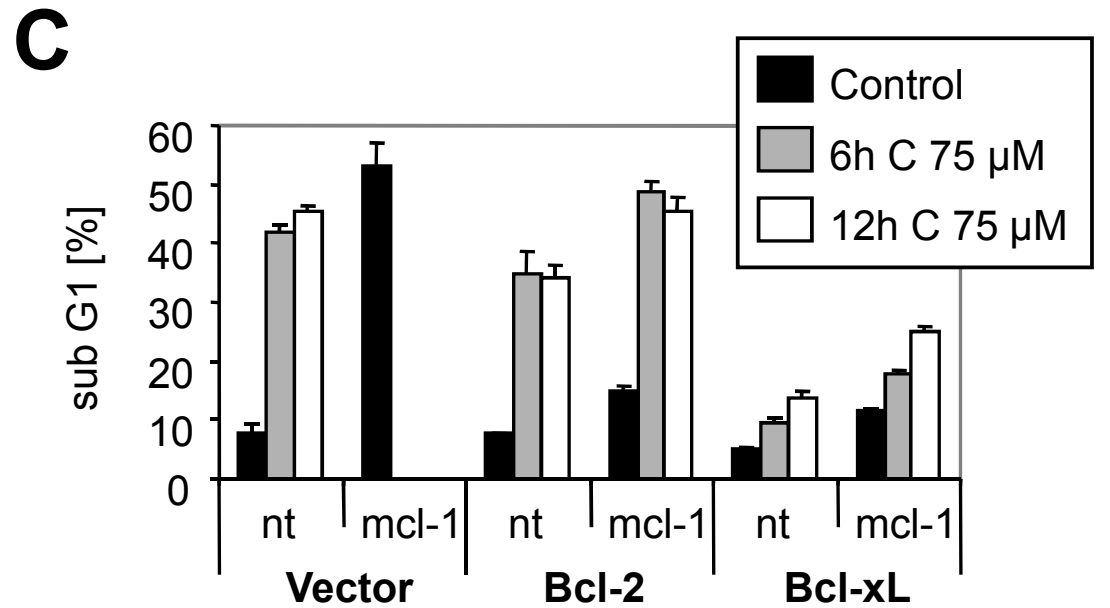

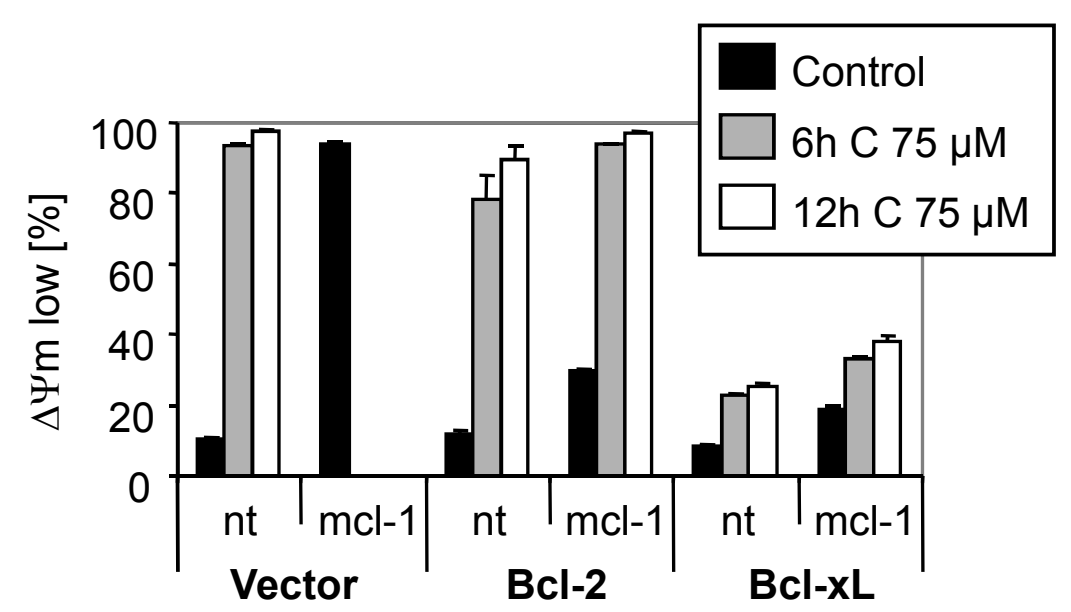


Fig 6
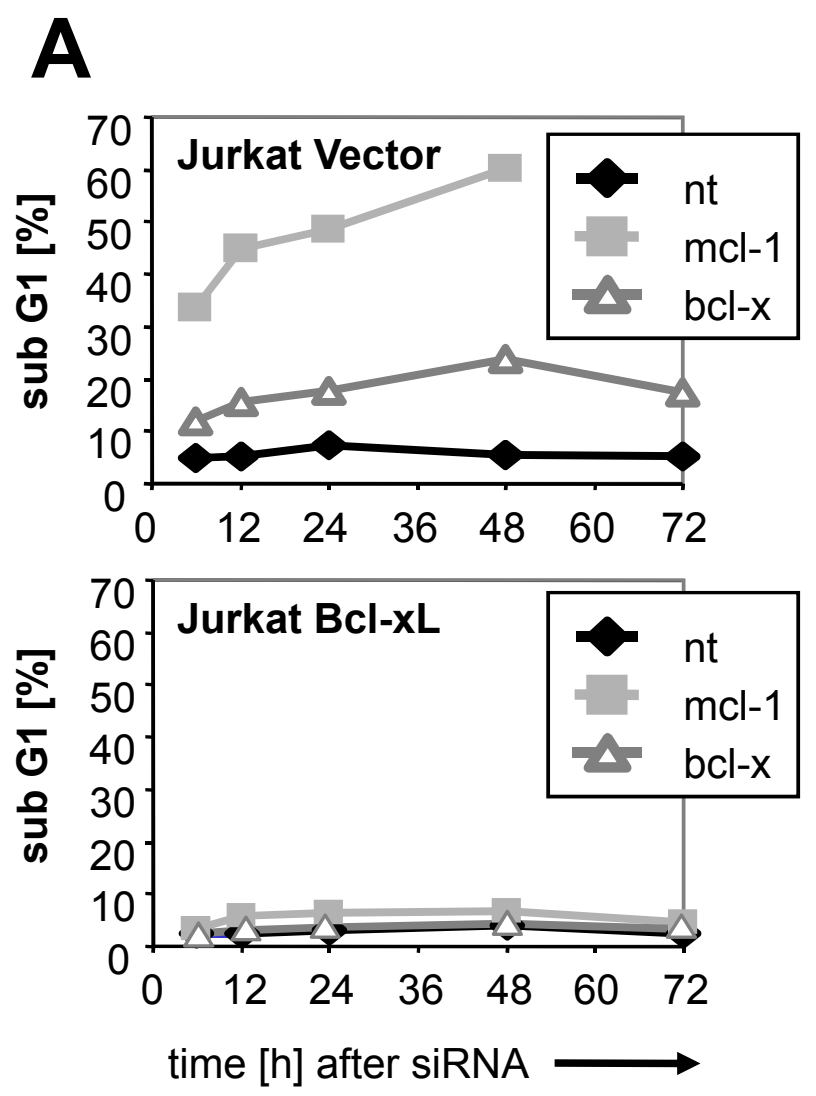

B

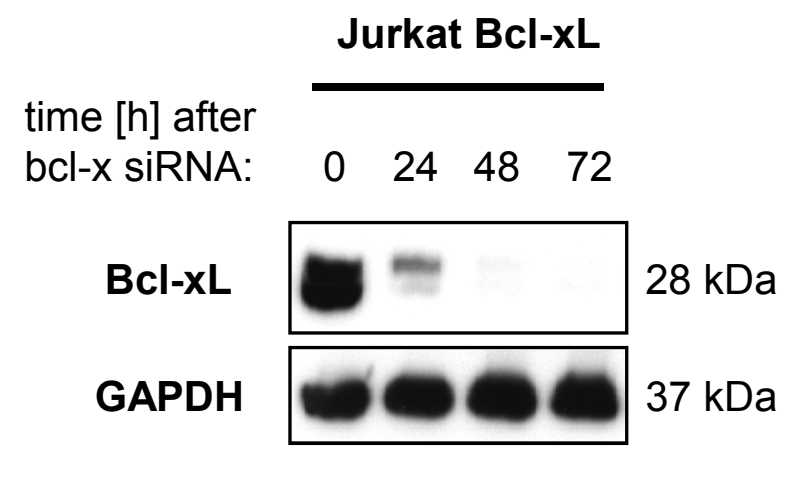

C
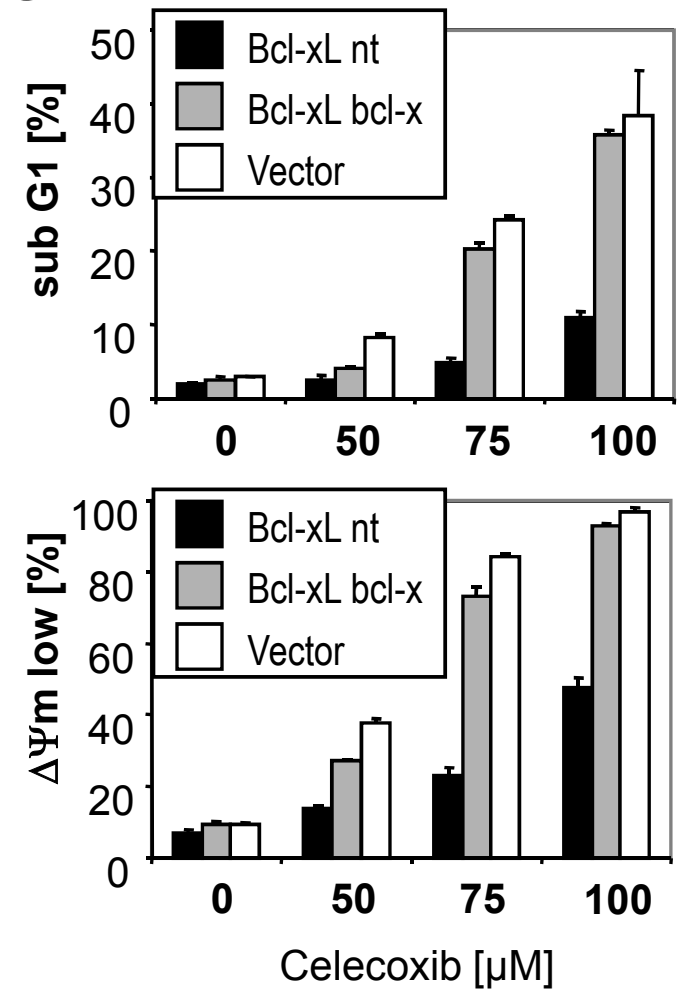

D

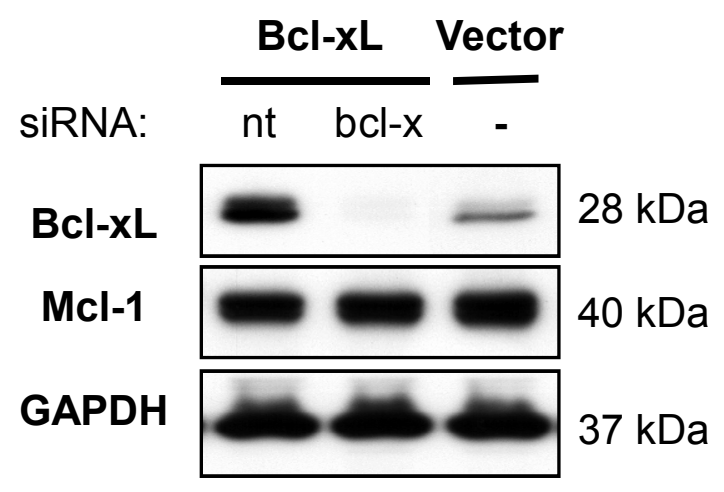

E
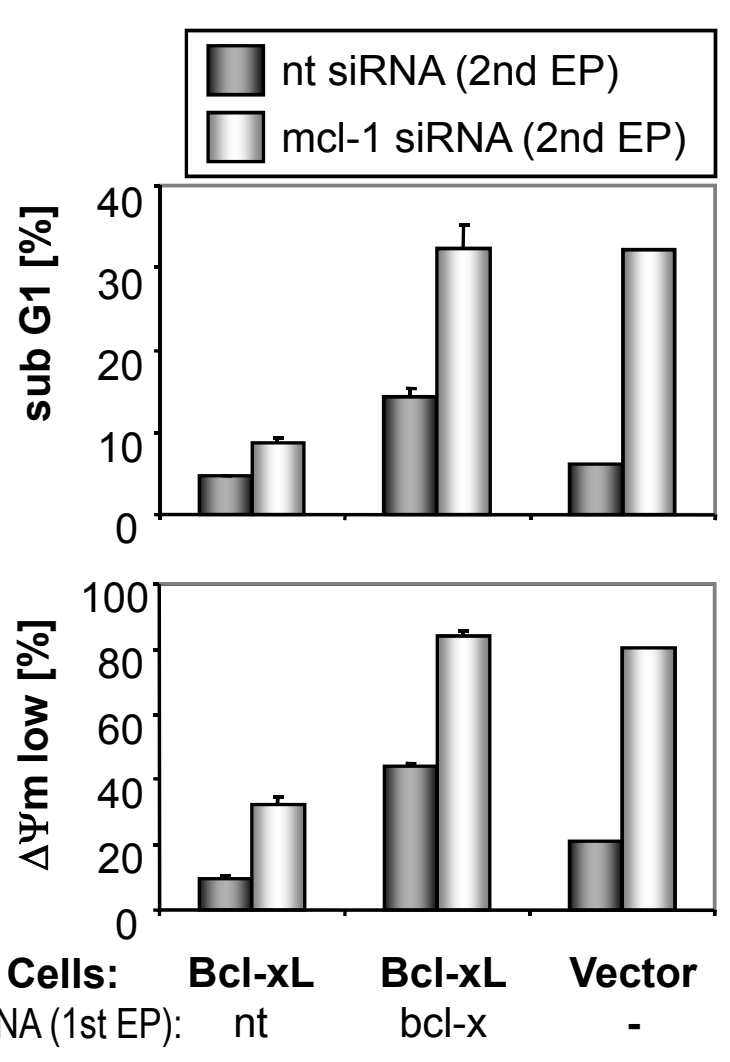

F

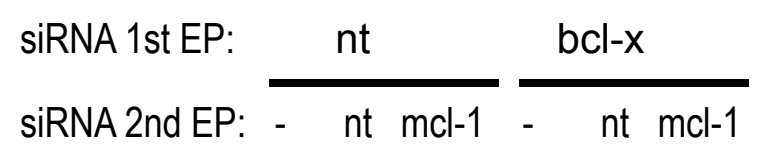

Bcl-xL $28 \mathrm{kDa}$

Mcl-1 40 kDa

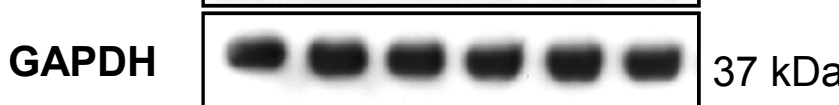




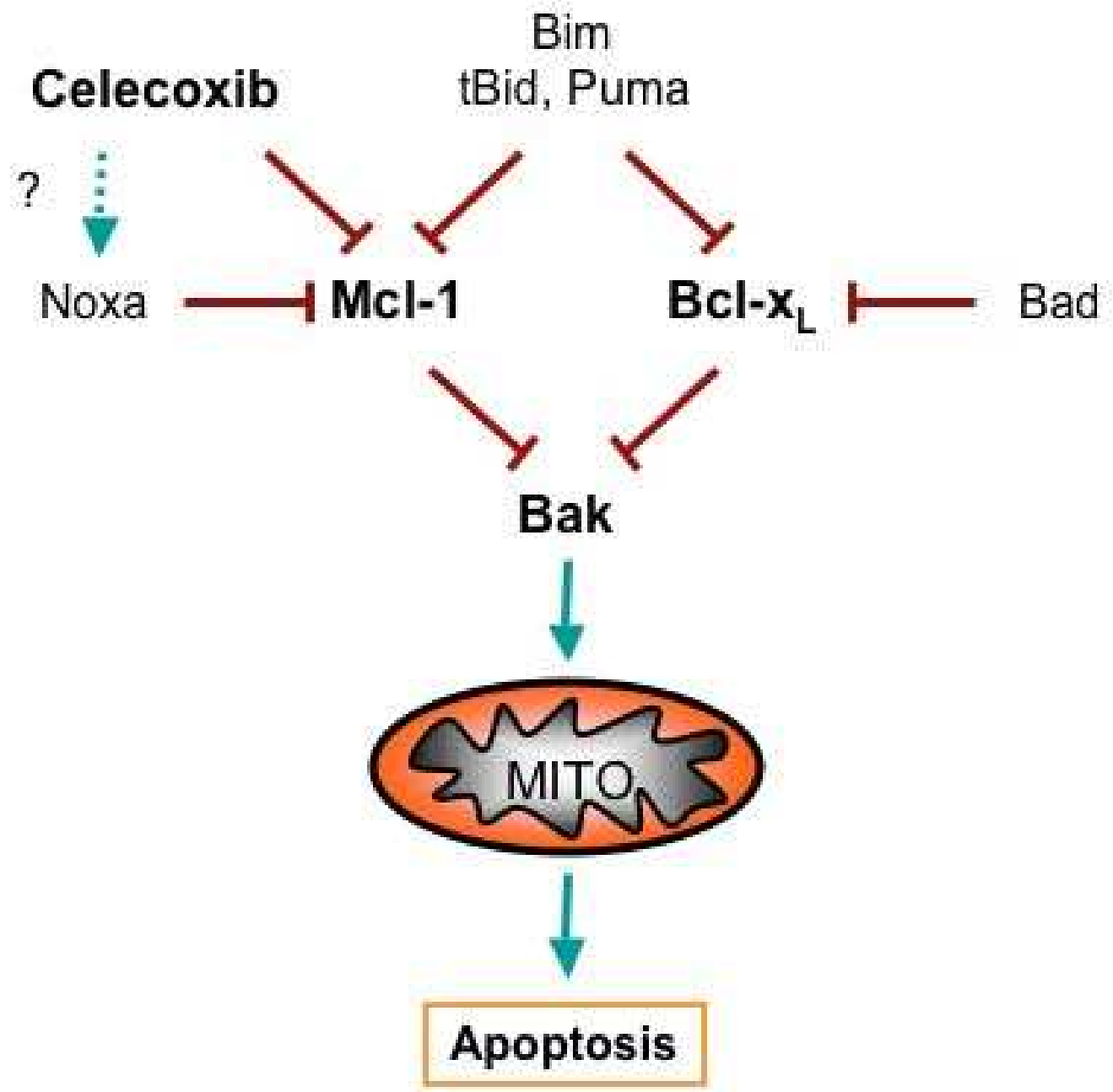

